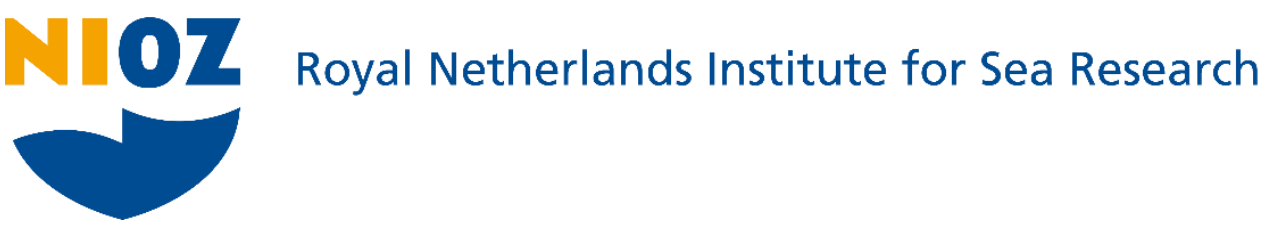

This is a pre-copyedited, author-produced version of an article accepted for publication, following peer review.

Jiang, L.; Soetaert, K. \& Gerkema, T. (2019). Decomposing the intraannual variability of flushing characteristics in a tidal bay along the North Sea. Journal of Sea Research, 115, 101821

Published version: https://dx.doi.org/10.1016/j.seares.2019.101821

NIOZ Repository: http://imis.nioz.nl/imis.php?module=ref\&refid=320985

[Article begins on next page]

The NIOZ Repository gives free access to the digital collection of the work of the Royal Netherlands Institute for Sea Research. This archive is managed according to the principles of the Open Access Movement, and the Open Archive Initiative. Each publication should be cited to its original source - please use the reference as presented.

When using parts of, or whole publications in your own work, permission from the author(s) or copyright holder(s) is always needed. 


\section{Decomposing the intra-annual variability of flushing characteristics in a tidal bay along the North Sea}

\section{Long Jiang $^{\mathrm{a}, \mathrm{b}, *}$, Karline Soetaert ${ }^{\mathrm{b}}$, Theo Gerkema ${ }^{\mathrm{b}}$}

${ }^{a}$ College of Oceanography, Hohai University, Nanjing, China

${ }^{\mathrm{b}}$ Department of Estuarine and Delta Systems, Royal Netherlands Institute for Sea Research (NIOZ) and Utrecht University, P.O. Box 140, 4400 AC Yerseke, The Netherlands.

${ }^{*}$ Corresponding author: L. Jiang (ljiang@hhu.edu.cn)

\section{Highlights:}

8 Large spatial and intra-annual variability in turnover times of the Oosterschelde

- Winds impact the local turnover time by up to \pm 50 days

0

- Density gradient and turnover time are regulated by neighboring river outflows

2

3

4

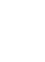




\section{Abstract}

Flushing timescales in estuaries and coastal bays largely shape the distribution of dissolved and particulate matter and therefore have important environmental implications. Here we investigate the spatiotemporal variability of turnover times in a semi-enclosed tidal bay and examine the potential underlying causes. The basin considered here is the Dutch coastal bay Oosterschelde (Eastern Scheldt in English) on the east coast of the North Sea. Using a calibrated and validated 3D hydrodynamic model, conservative tracer experiments were conducted to estimate turnover times. Sensitivity scenarios were run to examine the relative roles of tides, winds, and gravitational flow in driving the intra-annual variability. Results indicate that gravitational flow and winds contribute most to the intra-annual variability of turnover times in the Oosterschelde. Freshets from the Westerschelde and Rhine Rivers extending to the mouth of the bay can reduce the axial density gradient and gravitational flow, increasing turnover times of the basin. The prevailing southwesterly winds, when of sufficient magnitude $(>5 \mathrm{~m} / \mathrm{s}$ ), modify the spatial patterns of turnover times especially in shallow waters. Tides force flushing of the bay but do not induce significant intra-annual variability. Findings in this study underline the importance of intra-annual variability of turnover times in coastal bays and methodology proposed here facilitates intercomparison studies for other systems.

\section{Keywords}

Turnover time; tides; winds; gravitational force; intra-annual variability; tidal bay

\section{Introduction}

Estuaries and coastal bays are subject to natural and anthropogenic influences (e.g., sea level rise, eutrophication, pollution), posing growing threats to the sustainability of these systems. The spatiotemporal distribution of environmentally important dissolved and particulate substances (e.g., nutrients, chlorophyll-a, dissolved oxygen, trace metals, bacteria) can be interpreted by considering flushing timescales such as residence time, water age, turnover time, flushing time, renewal time, etc. (Banas et al., 2015; Guyondet et al., 2005; Josefson \& Rasmussen, 2000; Nixon et al., 1996; Prandle, 1984; Shen \& Wang, 2007; Soetaert \& Herman, 1995; Torréton et al., 2007; Wan et al., 2013). For example, a system with a flushing rate faster than the phytoplankton growth rate is relatively resistant to eutrophication and harmful algal blooms (Howarth et al., 2000; Wang et al., 2004). In ecosystems with intensive bivalve aquaculture, the production carrying capacity is considered to be exceeded when the residence time is longer than the clearance time needed for the cultured shellfish to filter the entire water column (Gibbs, 2007; Koutitonsky et al., 2004). In addition, system-wide flushing timescales are also applied as quantitative indicators to intercompare and categorize estuaries and coastal lagoons, as well as to divide basins into sub-regions (Abdelrhman, 2005; Ferrarin et al., 2013; Lemagie \& Lerczak, 2015; Plus et al., 2009; Umgiesser et al., 2014). Therefore, estimating flushing timescales is not only an essential step to understand transport processes in nearshore systems, but also of significant biogeochemical and ecological relevance.

Flushing of estuaries and coastal bays is a complicated process forced by freshwater runoff, tides, meteorological conditions, gravitational circulation, and their interaction with bathymetry and geometry of the system (Bárcena et al., 2012; Defne \& Ganju, 2015). River discharge is usually the first-order contributor to transport and flushing in many freshwaterfed estuaries (Du et al., 2018; Lemagie \& Lerczak, 2015; Shen \& Wang, 2007), while in tidal bays or lagoons where river runoff is limited, tides are the major force driving the water renewal (Cucco et al., 2009; Viero \& Defina, 2016; Yuan et al., 2007). Winds and 
gravitational forces have the potential to modulate transport processes via complex mechanisms (Banas \& Hickey, 2005; Choi \& Lee, 2004; Cucco \& Umgiesser, 2006; Tartinville et al., 1997; Webb \& Marr, 2016). Furthermore, the shape, geometry, and bathymetry of estuaries/lagoons can add to the spatial heterogeneity of flushing characteristics (Banas \& Hickey, 2005; Ferrarin et al., 2013; Umgiesser et al., 2014). Therefore, a systematic study of various processes is required to understand the flushing dynamics in these systems.

Dating back to Bolin \& Rodhe (1973), concepts like age, transit time, turnover time, and residence time have been used to quantify different kinds of renewal timescales in a reservoir. However, in theoretical and realistic oceanographic studies, they have been adopted with varying definitions and calculation methods. Lemagie \& Lerczak (2015), Monsen et al. (2002), Rayson et al. (2016), Viero \& Defina (2016), and many other studies reviewed and compared the main flushing timescales with practical examples and suggested that suitable timescales should be selected based on their definitions, computational costs, and the research objectives. Given the spatial heterogeneity in many systems, the bulk flushing timescales that treat the entire water body as a homogenous system (e.g., Lemagie \& Lerczak, 2015) are not generally suitable, but rather spatially-variable (or local) transport timescales should be estimated with a 2D or 3D hydrodynamic model. To this end, both Eulerian and Lagrangian approaches are applicable (Cucco et al., 2009). However, due to the chaotic stirring in tidedominated basins (Cucco et al., 2009; Ridderinkhof \& Zimmerman, 1992), accurate estimates of transport timescales with Lagrangian particles require releases at various tidal phases, statistical averaging based on numerous particles at any control region, and high-order (random-walk) schemes to interpret diffusion (Luff \& Pohlmann, 1995; Monsen et al., 2002; Oliveira \& Baptista, 1997; Sandery \& Kämpf, 2007). Thus, running intra-annual scenarios and sensitivity experiments with the Lagrangian method is computationally expensive (Rayson et al., 2016). Here we adopt turnover times, which represent the timescale of flushing a fraction $\left(e^{-1}\right)$ of original water mass out of a basin, as defined by Zimmerman (1976) and further described in section 3.2.

In a way, turnover times are a characteristic of a basin or bay, but in this study we put forward the notion that they are not a constant, but, in fact, vary considerably both spatially and temporally. We focus on intra-annual variability and the underlying mechanisms. As an example, we investigate the intra-annual variability of flushing capability in the Oosterschelde (Eastern Scheldt in English), a semi-enclosed tidal bay in the southwestern Netherlands (Fig. 1) with limited freshwater input due to the construction of dams and sluices, which isolate it from the surrounding rivers (Nienhuis \& Smaal, 1994). Given the computational efficiency and advantages in resolving diffusion, the Eulerian tracer approach is applied, using an existing 3D Oosterschelde hydrodynamic model driven by realistic external forcing (Jiang et al., 2019a). Using turnover time as an indicator, the magnitude and spatial patterns of intraannual flushing variability in the Oosterschelde are delineated. Sensitivity experiments of major forcing agents were conducted to understand the contributors to the intra-annual variability. The study thus aims to explore the driving mechanisms behind variability of turnover times and to provide reference for biogeochemical and ecological studies.

\section{The study site}

The $350-\mathrm{km}^{2}$ Oosterschelde is located in the southwestern delta of the Netherlands and connected to the North Sea through a storm surge barrier at its mouth (Fig. 1). Of the three openings of the storm surge barrier (Fig. 1), which are only closed during extreme weather conditions (roughly once a year, but not closed during our study period 2009-2010), the southern opening and channel account for the most (60\%) tidal flux into the basin (Eelkema et al., 2012). Vast shallow regions surrounding the tidal channels include a total of $110-\mathrm{km}^{2}$ 
intertidal flats that are important wildlife habitats (salt marshes, seagrass, water birds, and bivalves, Tangelder et al., 2012). However, due to reduced tidal currents in the post-barrier period, intertidal flats have slowly but continuously eroded, and sediments are deposited in tidal gullies (Eelkema et al., 2012; Nienhuis \& Smaal, 1994).

Prior physical and ecological studies usually divide the basin into four compartments (e.g., Jiang et al., 2019a; Smaal et al., 2001; Vroon, 1994; Wetsteyn \& Kromkamp, 1994), the western, central, eastern, and northern (Fig. 1). We added a "mouth" region outside the storm surge barrier to characterize water masses entering the basin, where salinity is influenced by the outflow of the Westerschelde and Rhine rivers, as well as the North Sea water (Fig. 1). Tides in the Oosterschelde are mostly semi-diurnal. The mean tidal range calculated from both tidal measurements by the Dutch government agency Rijkswaterstaat (https://waterinfo.rws.nl) and modeled water elevation (Jiang et al., 2019a) indicates an increase from $2.5 \mathrm{~m}$ at the mouth to $3.4 \mathrm{~m}$ at the eastern end. Salinity and temperature temporal variations are largely controlled by the tidal motion flushing the North Sea waters in and out, and vertical stratification is very limited (Wetsteyn \& Kromkamp, 1994). According to our recent cruise observations, the vertical salinity gradient is less than $0.017 \mathrm{~m}^{-1}$. The maximum tidal velocity is around $1-1.5 \mathrm{~m} \mathrm{~s}^{-1}$ in tidal channels (Mulder \& Louters, 1994). Due to the dominant role of tidal flushing, there is a seaward increasing gradient of many substances along the basin, for example, salinity, Chl-a, seston, and turbidity (Nienhuis \& Smaal, 1994; Wetsteyn \& Kromkamp, 1994). The overall freshwater inflow into the bay is below $10 \mathrm{~m}^{3} \mathrm{~s}^{-1}$ (Ysebaert et al., 2016). It was $3.2 \mathrm{~m}^{3} \mathrm{~s}^{-1}$ and $4.5 \mathrm{~m}^{3} \mathrm{~s}^{-1}$ in 2009 and 2010 , respectively (Rijkswaterstaat data). This is a negligible amount compared to the flushing of the basin by tidal exchange, which is $\sim 2 \times 10^{4} \mathrm{~m}^{3} \mathrm{~s}^{-1}$, estimated from a typical tidal prism of 9 $\times 10^{8} \mathrm{~m}^{3}$ in a 12-h tidal cycle (Table 1 ). The prevailing wind direction is southwesterly, especially in fall and winter, as revealed in the weather model data by the Royal Dutch Meteorological Institute (KNMI, Fig. 2) and by historical observations (Mulder \& Louters, 1994). However, occasionally, northeasterly winds are more frequent, for example, April to June in 2009 (Fig. 2b). Wind speeds are generally less than $10 \mathrm{~m} / \mathrm{s}$, but the frequency of strong winds (>15 $\mathrm{m} \mathrm{s}^{-1}$ ) increases in fall and winter (Fig. 2).

\section{Methods}

\subsection{Model description}

The flushing timescale is estimated using the open-source General Estuarine Transport Model (GETM, https://getm.eu), a finite-difference hydrostatic primitive-equation model that has been widely applied in estuaries and coastal bays in water exchange studies (e.g., Banas \& Hickey, 2005; Duran-Matute et al., 2014). GETM was run on a $300 \mathrm{~m} \times 300 \mathrm{~m}$ Cartesian grid with 10 uniform sigma layers for years 2009-2010. The model domain covers the Oosterschelde and part of the adjacent North Sea (Fig. 1) with a total of $237 \times 111$ grid cells. Our model solves flooding and drying of intertidal flats and 3D temperature, salinity, and current velocity forced with air-sea and open boundary conditions. The k- $\varepsilon$ turbulence closure scheme was computed in the 1D General Ocean Turbulence Model (GOTM) coupled with GETM. For the advection scheme of velocity and scalars (temperature, salinity, and tracer), we used the third-order total variation diminishing TVD-P2-PDM and second-order TVDSUPERBEE for horizontal and vertical dimensions, respectively, which are relatively computationally efficient (Banas \& Hickey, 2005).

Bathymetry of the Oosterschelde was interpolated from the regular measurements (resolution 20-200 m) by the Dutch government agency Rijkswaterstaat (accessible from http://opendap.deltares.nl/thredds/catalog/opendap/hydrografie/surveys/catalog.html). 
Atmospheric forcing including hourly mean winds, air pressure, air temperature, precipitation, and humidity was acquired from the KNMI model results (the downscaled 2.5-km resolution weather model HARMONIE). GETM uses the bulk formulae (Kondo, 1975) to compute the air-sea heat and momentum flux. We used the Flather boundary condition and have prescribed water level and 2D velocity on the open boundary, which were obtained from the output of the Northwest European Shelf tidal prediction and assimilation by Oregon State University (Egbert et al., 2010). Note that this tidal model does not include variations of sea surface height induced by remote wind forcing. The open-boundary temperature and salinity were provided by a 5-km-resolution North Sea model (van der Molen et al., 2016). Freshwater discharge into the northern branch (Fig. 1) was accessed from the Rijkswaterstaat website (https://waterinfo.rws.nl). The model displayed acceptable skills in reproducing realistic water level, current velocity, temperature, and salinity, and we refer to an earlier paper for details in detailed model setting, calibration and validation (Jiang et al., 2019a).

\subsection{Tracer experiment and calculation of flushing timescales}

The conservative Eulerian tracer was placed inside the Oosterschelde to estimate the flushing timescale based on its decay rate from the basin. We define the storm surge barrier as the natural boundary of the Oosterschelde, and the tracer was initialized at unity concentration in every grid cell inside the barrier, and zero outside.

There are many ways to quantify spatially-varying flushing timescales based on tracer decay. Residence time $\left(T_{r}\right)$ of every grid cell could be computed by integration of the remnant function (Takeoka, 1984), $T_{r}=\int_{0}^{\infty} C(t) / C_{0} d t$, where $C(t)$ and $C_{0}$ are the instantaneous and initial tracer concentration in each grid cell. Since flushing of the tracer inside the domain is never complete, a sufficiently long integration period (duration of the tracer experiment) needs to be arbitrarily defined (e.g., Wang et al., 2004; Yuan et al., 2007), which results in numerical inaccuracy and computational burden, especially for systems/sub-regions with long residence times (Viero \& Defina, 2016). An alternative timescale, turnover time $\left(T_{t}\right)$ as defined by Zimmerman (1976), is the time when $C(t)=e^{-1} C_{0}$. To estimate $T_{t}$, a much shorter model run is needed compared to $T_{r}$, and it does not need post-process integration for each grid cell, making it computationally efficient. Assuming that the tracer concentration decreases exponentially, i.e., $C(t)=C_{0} \cdot \exp \left(-t / T_{t}\right), T_{t}$ and $T_{r}$ are equivalent.

The exponential decay assumption holds when the system acts as a continuously stirred tank reactor (Monsen et al., 2002), which should be the case for each grid cell (Ahmed et al., 2017). In tide-dominated bays with negligible river discharge, $T_{t}$ is close to $T_{r}$ and suitable for representing the local flushing capability (Rayson et al., 2016; Viero \& Defina, 2016). The Oosterschelde is such a tide-dominated and well-mixed system (Section 2), in which the tracer decay is quasi-exponential in all compartments, and $T_{t}$ and $T_{r}$ show similar magnitude and spatial patterns (Jiang et al., 2019a). Besides turnover time, $T_{t}$ has been named flushing (Grifoll et al., 2013; Plus et al., 2009; Sandery \& Kämpf, 2007), renewal (Koutitonsky et al., 2004), residence (Abdelrhman, 2005), and influence time (Delhez et al., 2014).

After each model run, time series of the tracer concentration in each grid cell went through a 48-hour low-pass filter to remove the daily tidal signal, and the local $T_{t}$ is defined as the time when the filtered concentration fell to $e^{-1}$ of the initial concentration. $T_{t}$ in the entire basin and its four main compartments (Fig. 1) was derived by finding the $e^{-1}$ threshold in the decay curve of the basin- and compartment-wide integrated mass. 


\subsection{Intra-annual scenarios and sensitivity experiments}

In order to examine the intra-annual variability of turnover times in the Oosterschelde, tracer experiments were started at four different times in 2009, 1 January, 1 April, 1 July, and 1 October, following the method of Luff \& Pohlmann (1995) and Sandery \& Kämpf (2007). Each run lasted six months, slightly longer than the maximal $T_{t}$ in all grid cells. These intraannual scenarios were conducted under realistic forcing (R1, R4, R7, and R10 in Table 1). GETM allows decomposing the role of individual forcing agents by switching off others. Such sensitivity tests were performed to examine the relative importance of tides, winds, and gravitational force to the intra-annual variability of turnover times (Table 1). Given that the minimal freshwater flow from the northern branch lacks seasonality for being manipulated by sluice opening and only affects $T_{t}$ and salinity locally. Based on our prior examination of including and excluding freshwater discharge, the difference in $T_{t}$ is less than one day in the entire bay and its western, central, and eastern compartments. Thus, it is switched off in all the following sensitivity tests.

In this study, since the tidal phase vary in different parts of the basin (e.g., the lag of high tide is $\sim 30 \mathrm{~min}$ from the mouth to the head), the system-wide tidal phase is defined using the basin volume (Duran-Matute et al., 2014). Specifically, the time between two consecutive peaks/troughs of the Oosterschelde volume is considered as one tide cycle. When releasing tracer at five phases during one tidal cycle on 1 January 2009 (STP1-STP5 in Table 1), turnover time $T_{t}$ exhibited a dependence on the initial basin volume, but not on the direction of tidal currents. Experiments starting on high tides (a larger initial volume of tracer) generated $T_{t} \sim 10$ days longer than that starting on low tides (a smaller initial volume of tracer, Table 1). To exclude this effect from runs examining other forcing mechanisms, the initial basin volume of subsequent experiments was prescribed as $2.82 \mathrm{~km}^{3}$, the same as that at 9:00 on 1 January 2009 (STP2 in Table 1) and close to that at zero water level (Nienhuis \& Smaal, 1994). The tide-only STP2 case is the baseline scenario for subsequent runs; i.e., in any sensitivity runs, only one forcing agent was changed compared to STP2 (Table 1).

Since tides predominantly drive flushing of the Oosterschelde, we also studied the intra-annual variability of $T_{t}$ in experiments driven only by tides in different times of year were examined (STP2, STA4, STA7, and STA10 in Table 1), including two cases starting at spring and neap tides (STAsp and STAne in Table 1).

Wind impacts were assessed by imposing realistic winds in different times of year to the baseline scenario (W1, W4, W7, and W10 in Table 1). Since winds are highly variable with the period of a few days, we ran idealized experiments of fixed prevailing wind directions (southwesterly and northeasterly, Fig. 2) to better understand the wind-modulated flushing processes. Inspired by the method of Scully (2010), a time series was created where the wind magnitude changed sinusoidally from zero to a maximum speed with a period of three days. In accordance with the realistic wind distribution (Fig. 2), we used the maximum speed of $5 \mathrm{~m} / \mathrm{s}, 10 \mathrm{~m} / \mathrm{s}$, and $15 \mathrm{~m} / \mathrm{s}$ to represent weak, intermediate, and strong southwesterly winds (Wsw5, Wsw10, and Wsw15 in Table 1). One scenario (maximum $10 \mathrm{~m} / \mathrm{s}$, Wne10 in Table 1) was run for the less prevailing northeasterly winds.

The importance of density-driven (gravitational) flow varies among systems and different regions of a system (Babson et al., 2006; Choi \& Lee, 2004; Du et al., 2018) and is largely unknown in the Oosterschelde. The gravitational force induced by seasonal density variations was imposed to the baseline run to demonstrate the baroclinic impacts on the flushing timescale (G1, G4, G7, and G10 in Table 1). In this study, sigma-t, a unitless value equivalent to seawater density minus $1000 \mathrm{~kg} \mathrm{~m}^{-3}$, is used to denote seawater density (Fig. 3). Because of the temporally varying nature of density (Fig. 3), it is not easy to establish the 
direct connections between density gradient and $T_{t}$. Thus, we set up idealized "fixed-density" baroclinic runs in which density is determined by the initial condition and does not change with time. Events with low and high axial density gradients were selected during the year (Fig. 3) to feed the "fixed-density" runs (GF1-GF4 in Table 1).

\section{Intra-annual variability of turnover times}

The $T_{t}$ distribution in the realistic scenarios exhibited a west-east gradient with the longest $T_{t}$ appearing in the landward end of the eastern compartment (Figs. 4 and 5a). Along the $\mathrm{x}$ axis between 35 and $55 \mathrm{~km}, T_{t}$ was significantly shorter in the south of the basin than in the north (Fig. 5a), which indicates that the southern channel acts as the main conduit for tidal flushing. $T_{t}$ in the deep channels tended to be shorter than that in the surrounding shallow regions; for example, in the eastern compartment, the areas with relatively short $T_{t}$ marked the location of tidal channels (Fig. 4). These patterns in flushing timescales are also reported in other tidal systems, described as "tongue-shaped" distribution by Shen \& Wang (2007).

Table 1 shows $T_{t}$ of the entire bay and the least flushed eastern compartment, to indicate and intercompare the average and upper limit of the flushing timescale in all presented scenarios. When starting tracer experiments in different seasons, the basin-wide $T_{t}$ varies no longer than 10 days. However, significant intra-annual differences are manifested in the $T_{t}$ spatial distribution (Figs. 4 and 5). Directions and spacing of $T_{t}$ contours were highly variable in the central compartment (Fig. 4). The north of the western compartment is characterized by a large spatial $T_{t}$ gradient, as revealed by, for example, a 60-day $T_{t}$ variation within $5 \mathrm{~km}$ (Fig. 4a), as well as strong intra-annual variability (Fig. 5b). Besides this area, the intra-annual variability of $T_{t}$ was pronounced along the southern channel, and in the east of the eastern compartment (Fig. 5b). The longest $T_{t}$ of the basin ranges from 141 days (Fig. 5d) to 166 days (Fig. 5c). Overall, shorter $T_{t}$ was found in scenarios starting on 1 July (Fig. 4). The considerable intra-annual variability of $T_{t}$ implies that the Oosterschelde driven by realistic forcing is not at a steady state. In what follows, the contribution of individual forces is examined.

\subsection{The effects of tides on the intra-annual variability of turnover times}

As mentioned in Section 3.3, $T_{t}$ in the entire bay and four compartments differed up to 10 days when starting at various phases of a tidal cycle (STP1-STP5 in Table 1). With the similar initial basin volume, tracer experiments starting at flood (15:00) and ebb (09:00) tides generated similar $T_{t}$ (STP2 and STP4 in Table 1), which reveals that the initial basin volume, rather than the direction of tidal currents, is the major factor causing the $T_{t}$ variability when starting at different tidal phases.

The importance of tidal amplitude is shown by the fact that the residence time was almost doubled owing to the declined tidal amplitude after construction of the storm surge barrier (Nienhuis \& Smaal, 1994; Wetsteyn \& Kromkamp, 1994). However, over a time span comparable to $T_{t}$ ( $\sim 150$ days), with the same starting tidal phase and basin volume (Section 3.3), the average realistic tidal amplitude is relatively invariable; i.e., based on our calculation, the average tidal amplitude during Days 1-150 is nearly the same as that during Days 91-240, 121-270, 151-300, etc (standard deviation $2.8 \mathrm{~mm}$ ). Thus, in the tide-only scenarios with realistic tides starting at different times of year (STP2, STA4, STA7, and STA10 in Table 1), $T_{t}$ did not vary substantially (Table 1 ). The basin-wide and eastern-compartment turnover times estimated in the scenario starting at the spring tide are around two days shorter than those in the scenario starting at the neap tide (STAsp, and STAne in Table 1), which, nevertheless, is insufficient to explain the intra-annual variability in the realistic simulations. These findings indicate that tides are not a significant source of intra-annual variability. 


\subsection{The effects of winds on the intra-annual variability of turnover times}

The prevailing southwesterly winds varied in frequency and magnitude within the year 2009 (Fig. 2). Compared to the tide-only scenario, imposing winds did not exert a large change in the average $T_{t}$ of the entire bay but reduced the $T_{t}$ in the eastern compartment by $2-$ 14 days (Table 1). Spatially, similar wind-induced reduction in $T_{t}$ was manifested in many shallow regions including the north of the western compartment, southeast of the eastern compartment, and most of the northern branch (Figs. 6a-6d). Despite these similarities, the spatial patterns of $T_{t}$ differed due to the wind intra-annual variability (Figs. 6a-6d). Turnover times in these shallow regions were shorter in scenarios with winds starting in July and October (Figs. 6a-6d). $T_{t}$ in the central compartment in the scenario with winds starting on 1 October increased compared to the baseline scenario, which was not the case in the other three scenarios (Figs. 6a-6d). Given the high temporal variability of realistic winds, idealized winds were used to explore the wind-modulated spatial patterns in $T_{t}$ and understand the above findings.

Under southwesterly winds of maximum $5 \mathrm{~m} / \mathrm{s}$, the wind-driven changes in $T_{t}$ were limited to the eastern and northern compartments (Fig. 6e). When southwesterly winds were increased to maximum $10 \mathrm{~m} / \mathrm{s}$ and $15 \mathrm{~m} / \mathrm{s}$, the spatial pattern of $T_{t}$ resembled that driven by the realistic winds starting on 1 October (Figs. 6d, 6f, and 6g). Thus, southwesterly winds tended to increase $T_{t}$ in the central compartment and decrease it in many shallow (mostly $<5$ $\mathrm{m})$ areas of other compartments, and these effects strengthened with wind magnitude (Figs. $6 \mathrm{e}-6 \mathrm{~g}$ and 7). In contrast, under the less prevailing northeasterly winds of maximum $10 \mathrm{~m} / \mathrm{s}$, $T_{t}$ was reduced broadly in the eastern, northern, and central compartments and basin-wide (Fig. 6h and Table 1). These phenomena could be ascribed to the wind-driven circulation. In the residual current field driven by southwesterly winds, waters from the surrounding compartments were transported toward the central compartment, where a convergent anticlockwise gyre was generated (Fig. 8a) and tracer accumulated (Fig. 8c). Under the northeasterly winds, the residual currents were reversed and featured an outward flow (Fig. 8b), diminishing the tracer concentration in most of the basin (Fig. 8d).

It should be noted that, although idealized wind scenarios cannot be used directly for $T_{t}$ estimations, they do offer insight into the spatial patterns in the intra-annual scenarios. Southwesterly winds are frequent in all seasons (Fig. 2), so all scenarios driven by realistic winds demonstrate the typical patterns of southwesterly winds, that is, significant $T_{t}$ declines in most shallow waters (e.g., up to $5 \mathrm{~m}$ deep, Fig. 7). Due to the prevalence of strong (>10 $\mathrm{m} / \mathrm{s}$ ) southwesterly winds, increased $T_{t}$ was found in the central compartment in the scenario with winds starting on 1 October, a feature induced only by strong southwesterly winds (Figs. $2,6 \mathrm{~d}, 6 \mathrm{f}$, and $6 \mathrm{~g}$ ). In summary, it is found that winds of sufficient strength ( $>5 \mathrm{~m} / \mathrm{s}$ ) greatly altered the spatial heterogeneity of flushing characteristics. Although the average $T_{t}$ of the entire basin was not greatly changed by winds (Table 1), wind-induced changes in $T_{t}$ were as high as 40 days in certain regions (Fig. 6).

\subsection{The effects of gravitational flow on the intra-annual variability of turnover times}

The spatial density gradient in the Oosterschelde is shaped by temperature and salinity. The annual cycle of temperature causes density to be lower in summer and higher in winter (Fig. 3). However, it is salinity that has the main impact on spatial density variations. During freshet events of the Westerschelde and Rhine rivers, salinity at the southern and northern open boundaries can be lower than that in the Oosterschelde (e.g., Fig. 9a), reducing axial density gradient between the head and mouth of the basin (Fig. 3). When these two river plumes are so small that salinity near the mouth of the Oosterschelde is not greatly affected (e.g., Fig. 9b), the bay is characterized by a larger density gradient in the east-west direction 
(Fig. 3). Therefore, the salinity out of the mouth of the Oosterschelde is regulated by mixing of the North Sea water and outflow of the two rivers, and discharge and plume morphology of the two rivers seem to affect the horizontal density gradient in the Oosterschelde (Figs. 3 and 9).

The gravitational force induced by such density variations created substantial differences in the $T_{t}$ magnitude and distribution (Table 1 and Fig. 10). Because the densitydriven exchange flow favors flushing of the basin, $T_{t}$ was shortened in all four scenarios including it (Table 1 and Figs. 10a-10d). However, the extent of $T_{t}$ reduction varied dramatically among scenarios, and flushing was accelerated the most and least in Figs. 10c and 10a, respectively (see also Table 1). Given the density gradient dynamically changes within the duration of a scenario (6 months, Fig. 3), idealized scenarios with "fixed" density were examined to establish the relationship between density and $T_{t}$. When density was the only variable among scenarios and stationary with time, it is found that a relatively sharp axial density gradient promotes flushing by driving a strong bidirectional gravitational flow (Figs. 10e, 10f, and 11). The relationship between the axial density gradient, exchange flow, and $T_{t}$ was found to hold in the scenarios with realistic gravitational flow (Table 1 and Figs. 10a-10d and 12). Note that density and current results in Fig. 12 are 90-day averages to avoid overlaps of scenarios. Therefore, we conclude that intra-annual density variations exert a significant influence on flushing of the Oosterschelde.

\section{Discussion}

Of various methods used to evaluate the local flushing timescale of a tidal bay, our approach estimating turnover times with Eulerian tracer exhibits certain advantages. When examined at different tidal phases, results of our tracer experiments were insensitive to the initial direction of tidal currents (Table 1). This is different from the Lagrangian particletracking method, in which the phase of the initial tidal current is highly influential on movement of every single particle (Monsen et al., 2002; Oliveira \& Baptista, 1997). Our usage of turnover time, similar to the magnitude of residence time in tide-dominated systems (Jiang et al., 2019a; Viero \& Defina, 2016), is relatively computationally efficient, making it possible to run realistic and idealized sensitivity experiments decomposing the intra-annual variability. Approaches in this study are recommended to decipher the spatiotemporal variability of flushing processes in other tidal bays.

Of all the forces modulating flushing of the Oosterschelde, tides predominately drive the water renewal in the Oosterschelde, and flushing timescales would be indefinitely long without them. Effects of winds and gravitational flow on water renewal were manifested by modifying the tidal currents (e.g., Figs. 8 and 11). Tidal variations on daily (diurnal and semidiurnal) and biweekly (spring-neap) scales are found important to systems with flushing timescales of days to weeks, such as the estuaries of Richibucto (Guyondet et al., 2005), Danshuei River (Wang et al., 2004), Yaquina Bay (Lemagie \& Lerczak, 2015), Mersey (Yuan et al., 2007), Suances (Bárcena et al., 2012), Willapa Bay (Banas \& Hickey, 2005). However, the trimonthly and six-monthly average tidal amplitude were almost invariable (Section 4.1). The fact that starting the sensitivity experiments with tides of different seasons but the same phase (i.e., basin volume) resulted in insignificant changes in turnover times reveal that tidal and subtidal processes are not the dominant contributor to the $T_{t}$ in the Oosterschelde over the multi-month scale.

Compared to tides, the impacts of winds and gravitational flow are much more important in creating the intra-annual variability of turnover times in our system. Winds were responsible for altering the residual currents and redistributing the tracer concentration in the basin (Fig. 8), which induced different spatial patterns of turnover times. This mechanism 
resembles findings in the Venice Lagoon (Cucco \& Umgiesser, 2006). Shallow waters, where relatively weak winds can affect the local hydrodynamics, are particularly susceptible to wind forcing, as found in our results and previously (Geyer, 1997; Ranasinghe \& Pattiaratchi, 1998). In estuaries, wind-induced mixing can also modulate the density field and thus impact flushing (e.g., Du et al., 20018); however, this effect is not so important here according to our examination since tides are usually strong enough to mix the water column (Mulder \& Louters, 1994).

As a tidal bay, the horizontal density gradient in our system $\left(\Delta \mathrm{T}<3{ }^{\circ} \mathrm{C}\right.$ and $\Delta \mathrm{S}<3$ based on our 2-year simulation) is not as strong as in many river-dominated stratified estuaries such as Chesapeake and Mobile Bays, where gravitational flow is vital for flushing of the basin (Du et al., 2018; Shen \& Wang, 2007). In spite of the small density gradient in our study, gravitational exchange flow could reduce the flushing timescale substantially $(>20$ days) and vastly (Fig. 10). Thus, studies neglecting the gravitational force or vertical dynamics may lead to overestimates of flushing timescales, especially in systems with important buoyancy sources (e.g., Bárcena et al., 2012; Guyondet et al. 2005; Webb \& Marr, 2016).

In our model, tides are prescribed by imposing water elevation at the open boundary, which is optimized by data assimilation and validation of the shallow-water tides using tidal gauge data (Egbert et al., 2010). It should be noted that this open boundary water elevation, despite producing a good fit with the observed Oosterschelde water level in our model (Jiang et al., 2019a), does not include the subtidal effects on coastal sea surface height, which is mostly driven by remote winds (Frederikse and Gerkema, 2018). If the impacts of remote wind forcing are considered, the variability of turnover times should be enhanced in winter and fall since these two seasons are found to exhibit the largest wind-driven sea level variability along the North Sea coast (Frederikse and Gerkema, 2018).

\section{Summary and conclusions}

In this study, tracer experiments using realistic hydrodynamic model runs were used to investigate the intra-annual and spatial variability of turnover times in a tidal bay, the Oosterschelde. Our study displays the strong intra-annual spatial variability of turnover times in the Oosterschelde and its interactions with the basin geometry and bathymetry and sensitivity to various forcing. In such a dynamic system, spatially mapping of $T_{t}$ offers more information than a single bulk/integrative timescale for the whole basin or sub-region. For example, the basin-wide bulk turnover time was similar (85.9-89.2 days) among scenarios with tides and realistic winds (W1, W4, W7, and W10 in Table 1), whereas the spatial distribution varied strongly (Fig. 6a-6d).

The mechanisms behind the intra-annual variability were studied based on numerical experiments isolating certain processes while eliminating others. Our results indicate that turnover times in the Oosterschelde are sensitive to the initial basin volume but not to the starting tidal current directions. When starting the tracer experiments with the same initial volume (mass) of tracer, the starting tidal amplitude (spring vs neap) is also not a major source of the intra-annual variability of $T_{t}$. Compared to tides, winds and gravitational flow were found to be predominant in shaping the intra-annual and spatial patterns in $T_{t}$. For example, strong southwesterly winds were responsible for the relatively long $T_{t}$ in the central compartment in the intra-annual scenario starting on 1 October (Figs. 2 and 4); stronger density gradients along the main stem accounted largely for the overall faster flushing in the intra-annual scenarios starting on 1 July (Figs. 4 and 11). The role of gravitational force in promoting the basin flushing is further corroborated by "fixed-density" scenarios in which the density gradient is constant during experiments. 
Our results highlight the role of surrounding rivers, by acting as external buoyancy sources near the bay mouth, in mediating salinity and flushing of the Oosterschelde. In order to protect the shoreline from flooding and erosion, the southwestern delta in the Netherlands is highly manipulated by construction of dams and sluices, and opening of previously closed surrounding systems (e.g. Grevelingen and Haringvliet) is underway (van Haren, 2019; Ysebaert et al., 2016). Findings in this study imply that these engineering works should take the interaction of basins into account instead of focusing on a single system. Salinity changes in the coastal ocean can potentially change the flushing characteristics and ecosystem functions of each basin, since, for example, the Oosterschelde and Grevelingen, both used extensively for shellfish culture, can benefit from enhanced tidal import of seston from the North Sea (Smaal et al., 2013). Hence, continued oceanographic monitoring and numerical modeling covering the whole delta region are essential to understand the inter-basin dynamics and assisting environmental managers in decision-making.

A systematic examination of each forcing improves our understanding of flushing processes in a tidal bay. Compared to previous works, our results advance the efforts to interpret the mechanisms of wind- and density-driven circulation in this region. Here we examined the case of the Oosterschelde, but the approaches described here can be applied more generally to other tidal bays.

\section{Acknowledgments}

This work was supported by the post-doc framework of Utrecht University and Department of Estuarine and Delta Systems, NIOZ. We thank Johan van der Molen (NIOZ) for providing the open boundary conditions, Raymond Sluiter (KNMI) and Henk van den Brink (KNMI) for information on the meteorological data, and Marco Schrijver (Rijkswaterstaat) and Jan van 't Westende (Rijkswaterstaat) for sharing the velocity measurements. We thank two anonymous reviewers for their constructive comments on the manuscript.

\section{References}

Abdelrhman, M.A., 2005. Simplified modeling of flushing and residence times in 42 embayments in New England, USA, with special attention to Greenwich Bay, Rhode Island. Estuar. Coast. Shelf Sci. 62, 339-351.

Ahmed, A., Pelletier, G., Roberts, M., 2017. South Puget Sound flushing times and residual flows. Estuar. Coast. Shelf Sci. 187, 9-21.

Babson, A.L., Kawase, M., MacCready, P., 2006. Seasonal and interannual variability in the circulation of Puget Sound, Washington: a box model study. Atmos.-Ocean 44, 29-45.

Banas, N.S., Conway-Cranos, L., Sutherland, D.A., MacCready, P., Kiffney, P., Plummer, M., 2015. Patterns of river influence and connectivity among subbasins of Puget Sound, with application to bacterial and nutrient loading. Estuar. Coasts 38, 735-753.

Banas, N.S., Hickey, B.M., 2005. Mapping exchange and residence time in a model of Willapa Bay, Washington, a branching, macrotidal estuary. J. Geophys. Res. Oceans 110, C11011.

Bárcena, J.F., García, A., Gómez, A.G., Álvarez, C., Juanes, J.A., Revilla, J.A., 2012. Spatial and temporal flushing time approach in estuaries influenced by river and tide. An application in Suances Estuary (Northern Spain). Estuar. Coast. Shelf Sci. 112, 40-51.

Bolin, B., Rodhe, H., 1973, A note on the concepts of age distribution and transit time in natural reservoirs. Tellus 25, 58-62. 
Choi, K.W., Lee, J.H.W., 2004. Numerical determination of flushing time for stratified water bodies. J. Mar. Syst. 50, 263-281.

Cucco, A., Umgiesser, G., 2006. Modeling the Venice Lagoon residence time. Ecol. Model. 193, 34-51.

Cucco, A., Umgiesser, G., Ferrarin, C., Perilli, A., Canu, D.M., Solidoro, C., 2009. Eulerian and Lagrangian transport time scales of a tidal active coastal basin. Ecol. Model. 220, 913922.

Defne, Z., Ganju, N.K., 2015. Quantifying the residence time and flushing characteristics of a shallow, back-barrier estuary: Application of hydrodynamic and particle tracking models. Estuar. Coasts 38, 1719-1734.

Delhez, É.J., de Brye, B., de Brauwere, A., Deleersnijder, É., 2014. Residence time vs influence time. J. Mar. Syst. 132, 185-195.

Du, J., Park, K., Shen, J., Dzwonkowski, B., Yu, X., Yoon, B.I., 2018, Role of baroclinic processes on flushing characteristics in a highly stratified estuarine system, Mobile Bay, Alabama. J. Geophys. Res. Oceans, 123, 4518-4537.

Duran-Matute, M., Gerkema, T., De Boer, G.J., Nauw, J.J., Gräwe, U., 2014. Residual circulation and freshwater transport in the Dutch Wadden Sea: a numerical modelling study. Ocean Sci. 10, 611-632.

Eelkema, M., Wang, Z.B., Stive, M.J., 2012. Impact of back-barrier dams on the development of the ebb-tidal delta of the Eastern Scheldt. J. Coast. Res. 28, 1591-1605.

Egbert, G.D., Erofeeva, S.Y., Ray, R.D., 2010, Assimilation of altimetry data for nonlinear shallow-water tides: Quarter-diurnal tides of the Northwest European Shelf. Cont. Shelf Res. 30, 668-679.

Ferrarin, C., Bergamasco, A., Umgiesser, G., Cucco, A., 2013. Hydrodynamics and spatial zonation of the Capo Peloro coastal system (Sicily) through 3-D numerical modeling. J. Mar. Syst. 117, 96-107.

Frederikse, T., Gerkema, T., 2018, Multi-decadal variability in seasonal mean sea level along the North Sea coast. Ocean Sci. 14, 1491-1501.

Geyer, W.R., 1997. Influence of wind on dynamics and flushing of shallow estuaries. Estuar. Coast. Shelf Sci. 44, 713-722.

Gibbs, M.T., 2007. Sustainability performance indicators for suspended bivalve aquaculture activities. Ecol. Indic. 7, 94-107.

Grifoll, M., Del Campo, A., Espino, M., Mader, J., González, M., Borja, Á., 2013. Water renewal and risk assessment of water pollution in semi-enclosed domains: Application to Bilbao Harbour (Bay of Biscay). J. Mar. Syst. 109, S241-S251.

Guyondet, T., Koutitonsky, V.G., Roy, S., 2005. Effects of water renewal estimates on the oyster aquaculture potential of an inshore area. J. Mar. Syst. 58, 35-51.

Howarth, R.W., Swaney, D.P., Butler, T.J., Marino, R., 2000. Rapid communication: climatic control on eutrophication of the Hudson River Estuary. Ecosystems 3, 210-215.

Jiang, L., Gerkema, T., Wijsman, J. W., Soetaert, K., 2019a. Comparing physical and biological impacts on seston renewal in a tidal bay with extensive shellfish culture. J. Mar. Syst. 194, 102-110. 
Jiang, L., Soetaert, K., Gerkema, T., 2019b. Dataset for manuscript "Decomposing the intraannual variability of flushing characteristics in a tidal bay along the North Sea". Link of data repository: https://github.com/liiang2/os_intra-annual.

Josefson, A.B., Rasmussen, B., 2000. Nutrient retention by benthic macrofaunal biomass of Danish estuaries: importance of nutrient load and residence time. Estuar. Coast. Shelf Sci. 50, 205-216.

Kondo, J., 1975. Air-sea bulk transfer coefficients in diabatic conditions. Bound.-Layer Meteorol., 9, 91-112.

Koutitonsky, V.G., Guyondet, T., St-Hilaire, A., Courtenay, S.C., Bohgen, A., 2004. Water renewal estimates for aquaculture developments in the Richibucto estuary, Canada. Estuaries 27, 839-850.

Lemagie, E.P., Lerczak, J.A., 2015. A comparison of bulk estuarine turnover timescales to particle tracking timescales using a model of the Yaquina Bay estuary. Estuar. Coasts 38, 1797-1814.

Luff, R., Pohlmann, T., 1995. Calculation of water exchange times in the ICES-boxes with a eulerian dispersion model using a half-life time approach. Dtsch. Hydrogr. Z. 47, 287-299.

Monsen, N.E., Cloern, J.E., Lucas, L.V., Monismith, S.G., 2002. A comment on the use of flushing time, residence time, and age as transport time scales. Limnol. Oceanogr. 47, 15451553.

Mulder, J.P., Louters, T., 1994. Changes in basin geomorphology after implementation of the Oosterschelde estuary project. Hydrobiologia 282/283, 29-39.

Nienhuis, P.H., Smaal, A.C., 1994, The Oosterschelde estuary, a case-study of a changing ecosystem: an introduction. Hydrobiologia 282/283, 1-14.

Nixon, S.W., Ammerman, J.W., Atkinson, L.P., Berounsky, V.M., Billen, G., Boicourt, W.C., Boynton, W.R., Church, T.M., Ditoro, D.M., Elmgren, R., Garber, J.H., Giblin, A.E., Jahnke, R.A., Owens, N.J.P., Pilson, M.E.Q., Seitzinger, S.P., 1996. The fate of nitrogen and phosphorus at the land-sea margin of the North Atlantic Ocean. Biogeochemistry 35, 141180.

Oliveira, A., Baptista, A.M., 1997. Diagnostic modeling of residence times in estuaries. Water Resour. Res. 33, 1935-1946.

Plus, M., Dumas, F., Stanisière, J.Y., Maurer, D., 2009, Hydrodynamic characterization of the Arcachon Bay, using model-derived descriptors. Cont. Shelf Res. 29, 1008-1013.

Prandle, D., 1984. A modelling study of the mixing of 137Cs in the seas of the European continental shelf. Philos. Trans. Royal Soc. A 310, 407-436.

Ranasinghe, R., Pattiaratchi, C., 1998. Flushing characteristics of a seasonally-open tidal inlet: a numerical study. J. Coast. Res. 14, 1405-1421.

Rayson, M.D., Gross, E.S., Hetland, R.D., Fringer, O.B., 2016, Time scales in Galveston Bay: An unsteady estuary. J. Geophys. Res. Oceans 121, 2268-2285.

Ridderinkhof, H., Zimmerman, J.T.F., 1992. Chaotic stirring in a tidal system. Science 258, 1107-1111.

Sandery, P.A., Kämpf, J., 2007. Transport timescales for identifying seasonal variation in Bass Strait, south-eastern Australia. Estuar. Coast. Shelf Sci. 74, 684-696. 
Scully, M.E., 2010. Wind modulation of dissolved oxygen in Chesapeake Bay. Estuar. Coasts $33,1164-1175$.

Shen, J., Wang, H.V., 2007. Determining the age of water and long-term transport timescale of the Chesapeake Bay. Estuar. Coast. Shelf Sci. 74, 585-598.

Smaal, A.C., Schellekens, T., van Stralen, M.R., Kromkamp, J.C., 2013. Decrease of the carrying capacity of the Oosterschelde estuary (SW Delta, NL) for bivalve filter feeders due to overgrazing? Aquaculture 404, 28-34.

Smaal, A.C., van Stralen, M.R., Schuiling, E., 2001. The interaction between shellfish culture and ecosystem processes. Can. J. Fish. Aquat. Sci. 58, 991-1002.

Soetaert, K., Herman, P.M., 1995, Estimating estuarine residence times in the Westerschelde (The Netherlands) using a box model with fixed dispersion coefficients. Hydrobiologia 311, 215-224.

Takeoka, H., 1984. Fundamental concepts of exchange and transport time scales in a coastal sea. Cont. Shelf Res. 3, 311-326.

Tangelder, M., Troost, K., van den Ende, D., Ysebaert, T., 2012. Biodiversity in a changing Oosterschelde: from past to present. Wettelijke Onderzoekstaken Natuur \& Milieu, WOT work document 288. 52p.

Tartinville, B., Deleersnijder, E., Rancher, J., 1997. The water residence time in the Mururoa atoll lagoon: sensitivity analysis of a three-dimensional model. Coral Reefs 16, 193-203.

Torréton, J.P., Rochelle-Newall, E., Jouon, A., Faure, V., Jacquet, S., Douillet, P., 2007. Correspondence between the distribution of hydrodynamic time parameters and the distribution of biological and chemical variables in a semi-enclosed coral reef lagoon. Estuar. Coast. Shelf Sci. 74, 766-776.

Umgiesser, G., Ferrarin, C., Cucco, A., De Pascalis, F., Bellafiore, D., Ghezzo, M., Bajo, M., 2014. Comparative hydrodynamics of 10 Mediterranean lagoons by means of numerical modeling. J. Geophys. Res. Oceans 119, 2212-2226.

van der Molen, J., Ruardij, P., Greenwood, N., 2016. Potential environmental impact of tidal energy extraction in the Pentland Firth at large spatial scales: results of a biogeochemical model. Biogeosciences 13, 2593-2609.

van Haren, H., 2019. Internal wave mixing in warming lake Grevelingen. Estuar. Coast. Shelf Sci. 226, 106298.

Viero, D.P., Defina, A., 2016, Water age, exposure time, and local flushing time in semienclosed, tidal basins with negligible freshwater inflow. J. Mar. Syst. 156, 16-29.

Vroon, J., 1994, Hydrodynamic characteristics of the Oosterschelde in recent decades. Hydrobiologia 282/283, 17-27.

Wan, Y., Qiu, C., Doering, P., Ashton, M., Sun, D., Coley, T., 2013. Modeling residence time with a three-dimensional hydrodynamic model: Linkage with chlorophyll a in a subtropical estuary. Ecol. Model. 268, 93-102.

Wang, C.F., Hsu, M.H., Kuo, A.Y., 2004. Residence time of the Danshuei River estuary, Taiwan. Estuar. Coast. Shelf Sci. 60, 381-393.

Webb, B.M., Marr, C., 2016. Spatial variability of hydrodynamic timescales in a broad and shallow estuary: Mobile Bay, Alabama. J. Coast. Res. 32, 1374-1388. 
628 Wetsteyn, L.P.M.J., Kromkamp, J.C., 1994. Turbidity, nutrients and phytoplankton primary 629 production in the Oosterschelde (The Netherlands) before, during and after a large-scale 630 coastal engineering project (1980-1990). Hydrobiologia 282/283, 61-78.

631 Ysebaert, T., van der Hoek, D.J., Wortelboer, R., Wijsman, J.W.M., Tangelder, M., Nolte, A., 632 2016. Management options for restoring estuarine dynamics and implications for ecosystems: 633 A quantitative approach for the Southwest Delta in the Netherlands. Ocean Coast. Manag. $634121,33-48$.

635 Yuan, D., Lin, B., Falconer, R.A., 2007. A modelling study of residence time in a macro-tidal 636 estuary. Estuar. Coast. Shelf Sci., 71, 401-411.

637 Zimmerman, J.T.F. (1976), Mixing and flushing of tidal embayments in the western Dutch 638 Wadden Sea part I: Distribution of salinity and calculation of mixing time scales. Neth. J. Sea 639 Res. 10, 149-191. 
Table 1. A list of model runs with tracer experiments and the resulting turnover times $\left(T_{t}\right)$ in the year 2009. Five tidal phases in STP1-STP5

\begin{tabular}{|c|c|c|c|c|c|c|c|c|}
\hline $\begin{array}{l}\text { Run } \\
\text { name }\end{array}$ & Startup time & $\begin{array}{l}\text { Initial basin } \\
\text { volume }\left(\mathrm{km}^{3}\right)\end{array}$ & $\begin{array}{l}\text { Startup Temperature / } \\
\text { Salinity }\end{array}$ & Tides & Winds & $\begin{array}{l}\text { Density } \\
\text { calculation }\end{array}$ & $\begin{array}{l}T_{t} \text { (days) } \\
\text { basin- } \\
\text { wide } \\
\end{array}$ & $\begin{array}{l}T_{t} \text { (days) } \\
\text { eastern } \\
\text { compartment }\end{array}$ \\
\hline \multicolumn{9}{|c|}{ Realistic intra-annual runs } \\
\hline $\mathrm{R} 1$ & 1 Jan. 0:00 & 2.68 & Realistic & Realistic & Realistic & Baroclinic & 81.7 & 137.1 \\
\hline $\mathrm{R} 4$ & 1 Apr. 0:00 & 2.48 & Realistic & Realistic & Realistic & Baroclinic & 74.6 & 134.5 \\
\hline R7 & 1 Jul. 0:00 & 2.88 & Realistic & Realistic & Realistic & Baroclinic & 79.8 & 129.5 \\
\hline $\mathrm{R} 10$ & 1 Oct. 0:00 & 3.15 & Realistic & Realistic & Realistic & Baroclinic & 81.5 & 136.8 \\
\hline \multicolumn{9}{|c|}{ Sensitivity runs of the startup tidal phase } \\
\hline STP1 & 1 Jan. 06:00 & 3.37 & No & Realistic & No & Barotropic & 92.9 & 153.5 \\
\hline STP2 & 1 Jan. 09:00 & 2.82 & No & Realistic & No & Barotropic & 87.2 & 147.7 \\
\hline STP3 & 1 Jan. 12:00 & 2.39 & No & Realistic & No & Barotropic & 83.7 & 143.5 \\
\hline STP4 & 1 Jan. 15:00 & 2.59 & No & Realistic & No & Barotropic & 85.3 & 145.4 \\
\hline STP5 & 1 Jan. 18:00 & 3.29 & No & Realistic & No & Barotropic & 92.4 & 152.9 \\
\hline \multicolumn{9}{|c|}{ Sensitivity runs of the startup tidal amplitude } \\
\hline STA4 & 1 Jan. 09:00 & 2.82 & No & Realistic starting on 1 Apr. & No & Barotropic & 88.6 & 148.3 \\
\hline STA7 & 1 Jan. 09:00 & 2.82 & No & Realistic starting on $1 \mathrm{Jul}$. & No & Barotropic & 89.3 & 149.9 \\
\hline STA10 & 1 Jan. 09:00 & 2.82 & No & Realistic starting on 1 Oct. & No & Barotropic & 87.9 & 149.3 \\
\hline STAsp & 1 Jan. 09:00 & 2.82 & No & Realistic starting on 13 Jan. & No & Barotropic & 87.0 & 148.3 \\
\hline STAne & 1 Jan. 09:00 & 2.82 & No & Realistic starting on 20 Jan. & No & Barotropic & 89.1 & 150.8 \\
\hline \multicolumn{9}{|c|}{ Sensitivity runs of winds } \\
\hline W1 & 1 Jan. 09:00 & 2.82 & No & Realistic starting on 1 Jan. & Realistic & Barotropic & 86.9 & 142.1 \\
\hline W4 & 1 Jan. 09:00 & 2.82 & No & Realistic starting on 1 Jan. & Realistic starting on 1 Apr. & Barotropic & 85.9 & 141.4 \\
\hline W7 & 1 Jan. 09:00 & 2.82 & No & Realistic starting on 1 Jan. & Realistic starting on $1 \mathrm{Jul}$. & Barotropic & 86.2 & 133.5 \\
\hline W10 & 1 Jan. 09:00 & 2.82 & No & Realistic starting on 1 Jan. & Realistic starting on 1 Oct. & Barotropic & 88.2 & 145.1 \\
\hline Wsw5 & 1 Jan. 09:00 & 2.82 & No & Realistic starting on 1 Jan. & Southwesterly $5 \mathrm{~m} / \mathrm{s}$ & Barotropic & 89.7 & 148.5 \\
\hline Wsw10 & 1 Jan. 09:00 & 2.82 & No & Realistic starting on 1 Jan. & Southwesterly $10 \mathrm{~m} / \mathrm{s}$ & Barotropic & 95.8 & 148.3 \\
\hline Wsw15 & 1 Jan. 09:00 & 2.82 & No & Realistic starting on 1 Jan. & Southwesterly $15 \mathrm{~m} / \mathrm{s}$ & Barotropic & 90.2 & 143.9 \\
\hline Wne10 & 1 Jan. 09:00 & 2.82 & No & Realistic starting on 1 Jan. & Northeasterly $10 \mathrm{~m} / \mathrm{s}$ & Barotropic & 71.1 & 116.5 \\
\hline
\end{tabular}




\begin{tabular}{|c|c|c|c|c|c|c|c|c|}
\hline \multicolumn{9}{|c|}{ Sensitivity runs of gravitational flow } \\
\hline G1 & 1 Jan. 09:00 & 2.82 & Realistic & Realistic starting on 1 Jan. & No & Baroclinic & 84.0 & 143.6 \\
\hline G4 & 1 Jan. 09:00 & 2.82 & Realistic starting on 1 Apr. & Realistic starting on 1 Jan. & No & Baroclinic & 73.7 & 117.3 \\
\hline G7 & 1 Jan. 09:00 & 2.82 & Realistic starting on $1 \mathrm{Jul}$. & Realistic starting on 1 Jan. & No & Baroclinic & 66.4 & 113.7 \\
\hline G10 & 1 Jan. 09:00 & 2.82 & Realistic starting on 1 Oct. & Realistic starting on 1 Jan. & No & Baroclinic & 75.2 & 129.5 \\
\hline $\mathrm{GF} 1^{\mathrm{h}}$ & 1 Jan. 09:00 & 2.82 & 25 Feb. "fixed" & Realistic starting on 1 Jan. & No & Baroclinic & 85.0 & 147.0 \\
\hline $\mathrm{GF}^{\mathrm{h}}$ & 1 Jan. 09:00 & 2.82 & 26 Aug. "fixed" & Realistic starting on 1 Jan. & No & Baroclinic & 69.5 & 125.3 \\
\hline $\mathrm{GF}^{\mathrm{h}}$ & 1 Jan. 09:00 & 2.82 & 21 Sep. "fixed" & Realistic starting on 1 Jan. & No & Baroclinic & 83.3 & 146.0 \\
\hline $\mathrm{GF}^{\mathrm{h}}$ & 1 Jan. 09:00 & 2.82 & 21 Dec. "fixed" & Realistic starting on 1 Jan. & No & Baroclinic & 67.9 & 119.2 \\
\hline
\end{tabular}




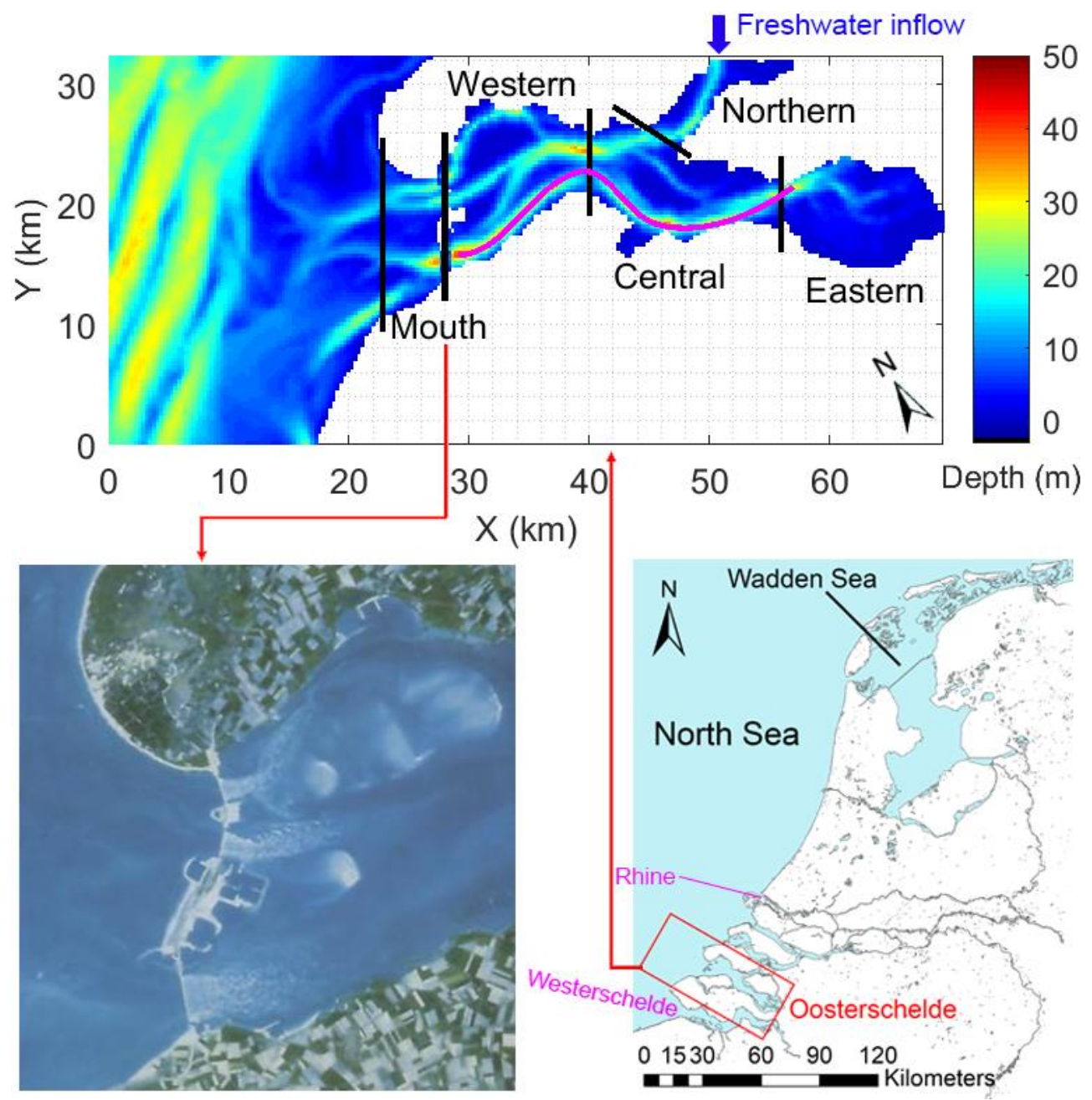

646 Fig. 1. The model domain and bathymetry covering the Oosterschelde and part of the 647 southern North Sea. The black lines in the left panel divide the Oosterschelde into four 648 compartments (western, central, eastern, and northern) and a "mouth" region. The pink line in 649 the left panel denotes a transact along the main (southern) channel of the basin. An aerial 650 image of the bay mouth (Photograph by National Aerospace Laboratory, Amsterdam, 651 published in Nienhuis and Smaal, 1994) shows three opening of the storm surge barrier. 

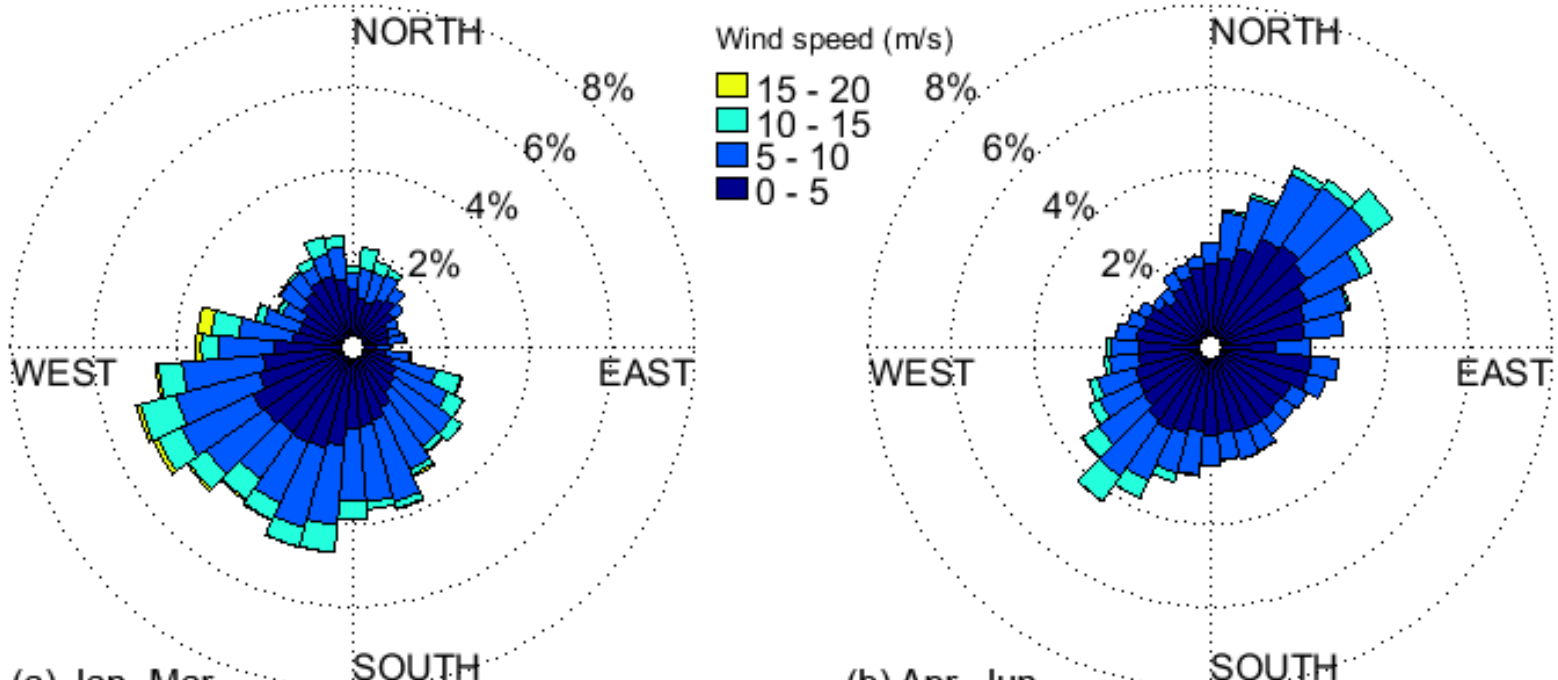

652

(a) Jan.-Mar.

(b) Apr.-Jun.

SOUTH

(c) Jul.-Sep

(d) Oct.-Dec
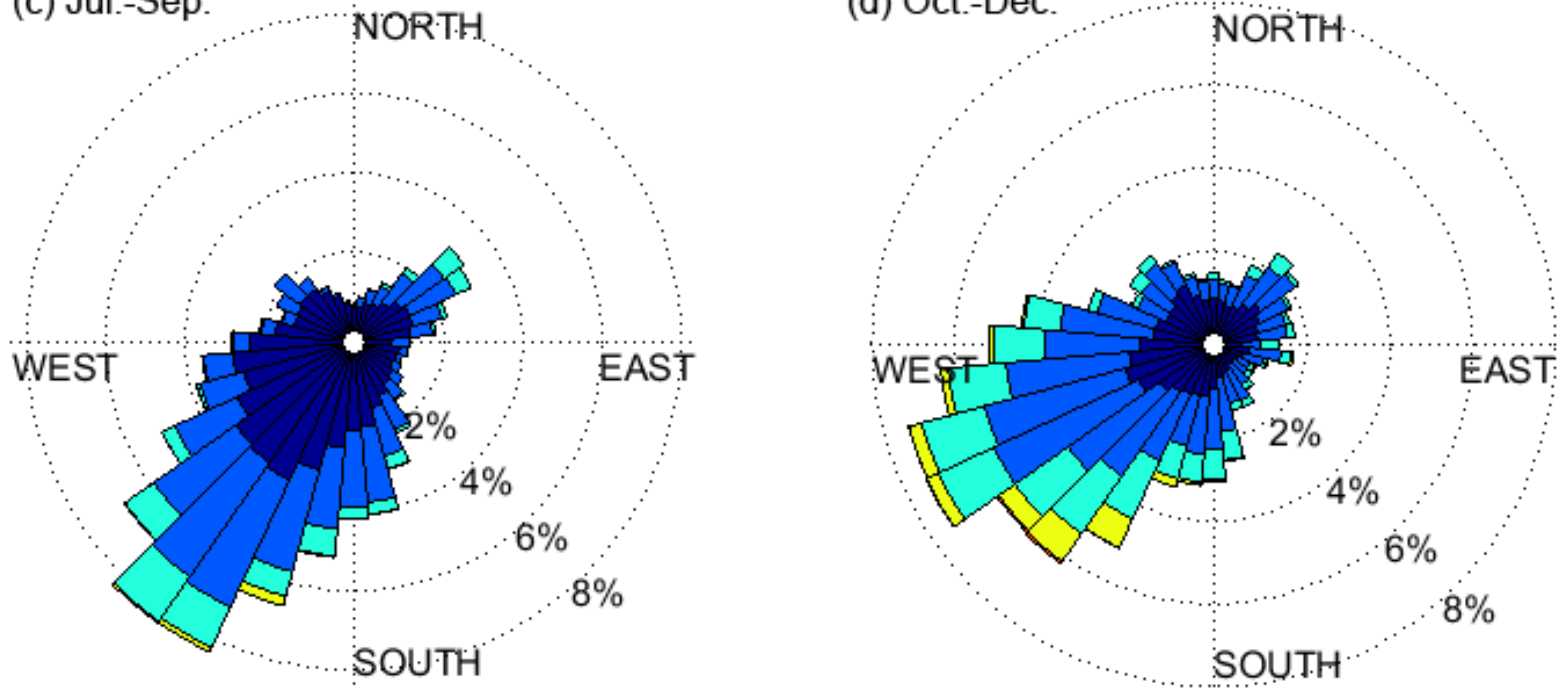

Fig. 2. Trimonthly wind roses over the Oosterschelde in 2009. Wind data are provided by a downscaled weather model HARMONIE with a horizontal grid of $2.5 \mathrm{~km}$ produced by the Royal Dutch Meteorological Institute (KNMI). 


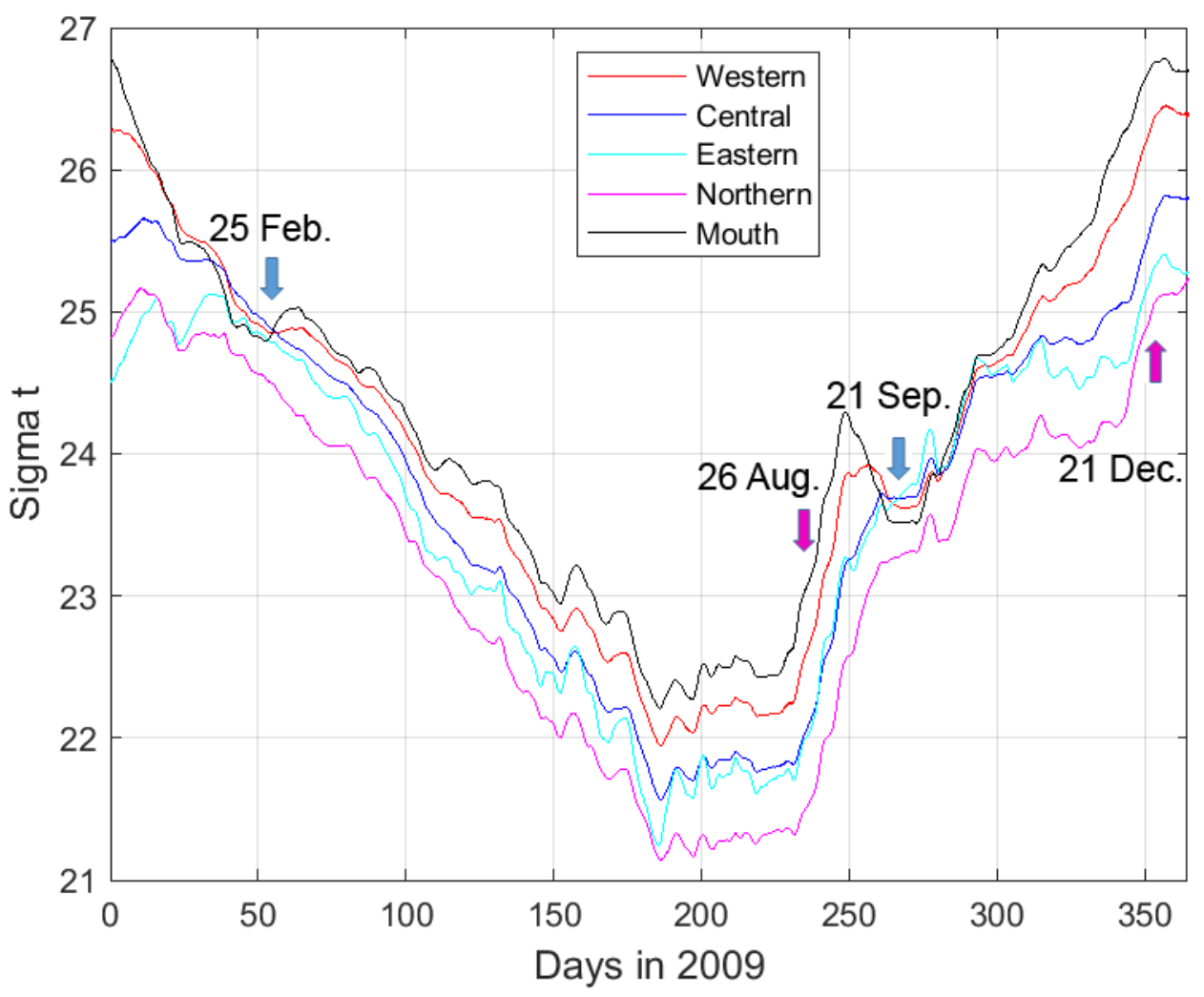

657 Fig. 3. Simulated spatially average sigma-t in four compartments and the area "mouth" in the 658 Oosterschelde in 2009. Sigma-t is a dimensionless quantity subtracting $1000 \mathrm{~kg} \mathrm{~m}^{-3}$ from the 659 density of seawater, e,g, a sigma-t value of 25 denotes the seawater density $1025 \mathrm{kgm}^{-3}$. Four 660 dates marked were used for initial conditions of idealized "fixed-density" scenarios (Table 1). 661 See Fig. 1 for the division of these sub-regions. 

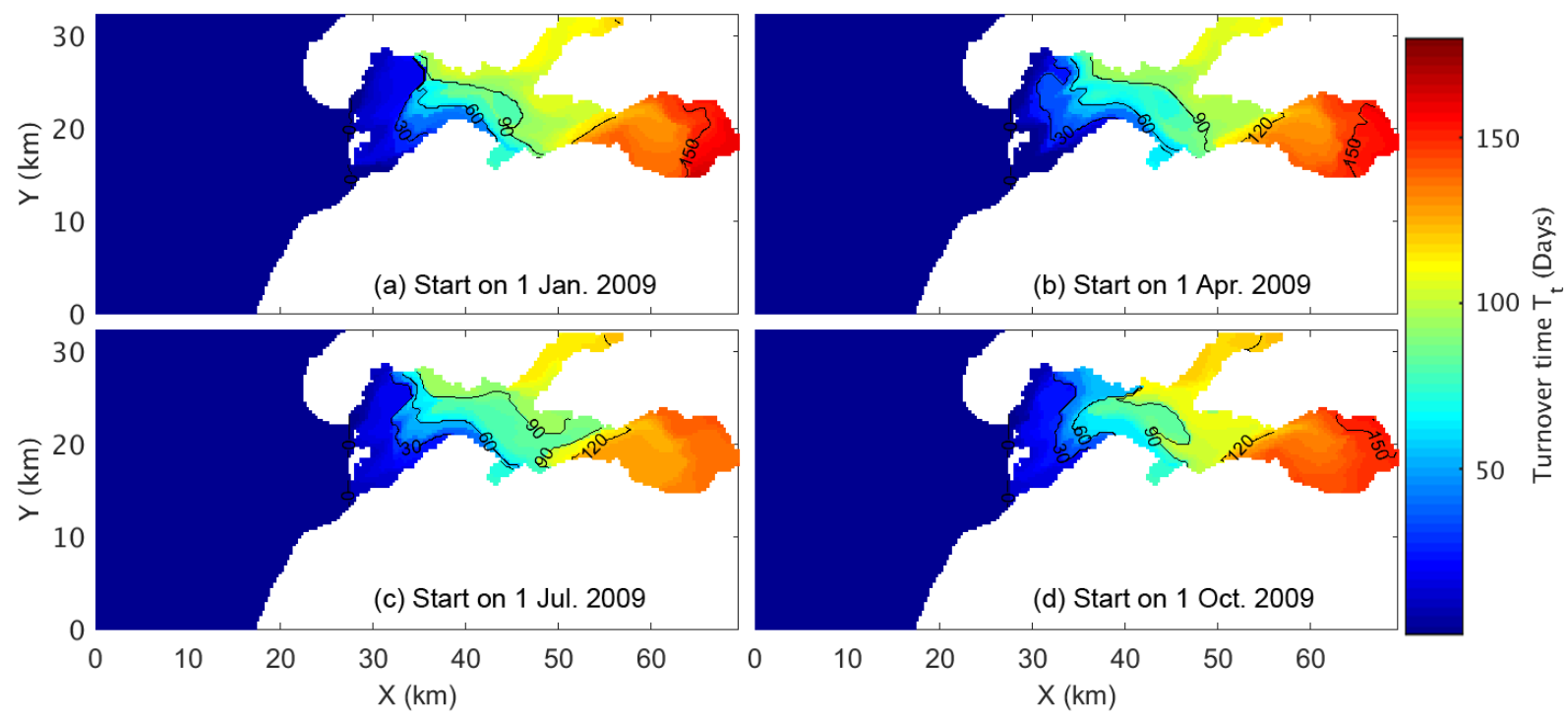

Fig. 4. Turnover time of four realistic scenarios initiating on (a) 1 January, (b) 1 April, (c) 1 

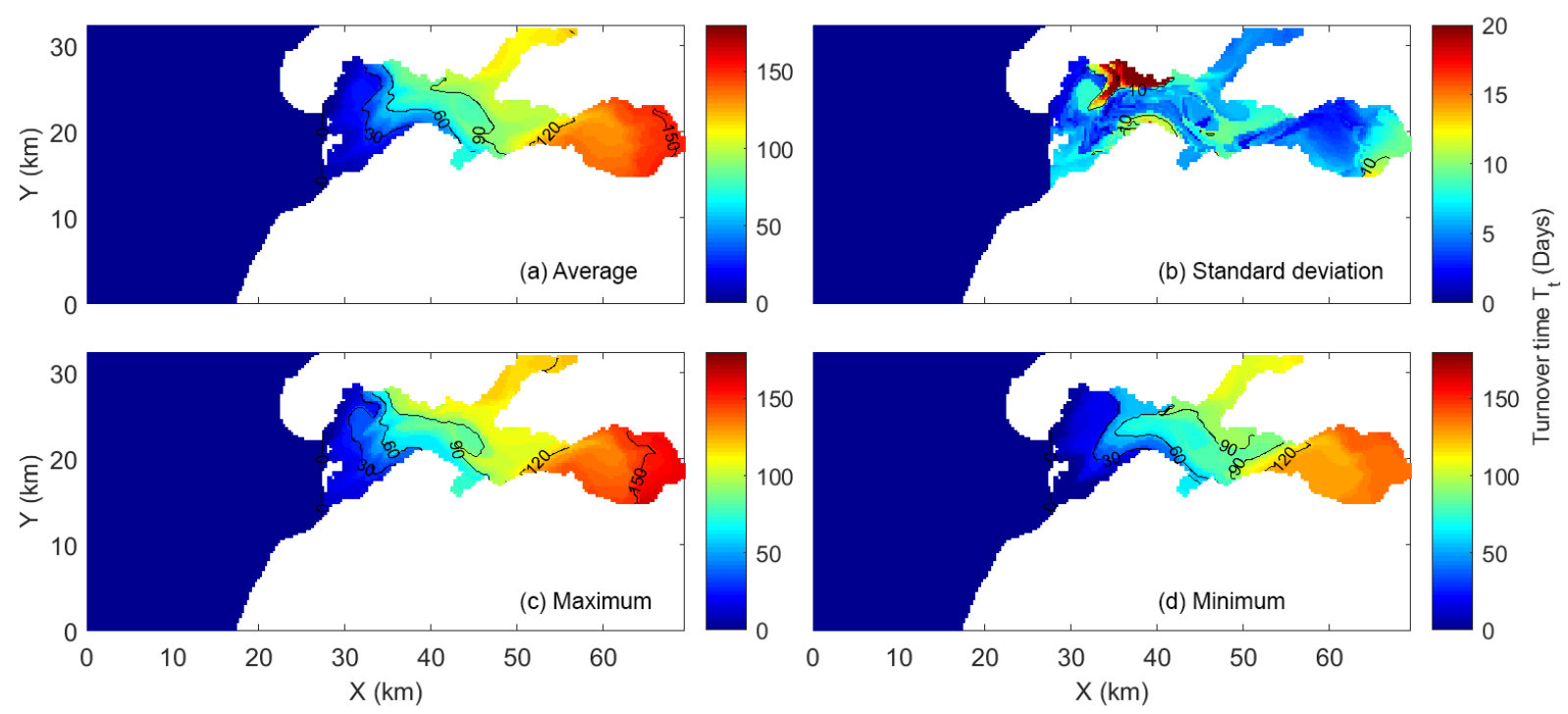

681

Fig. 5. (a) Average, (b) standard deviation, (c) maximum, and (d) minimum of turnover time 683 in the four scenarios shown in Fig. 4.

684

685 


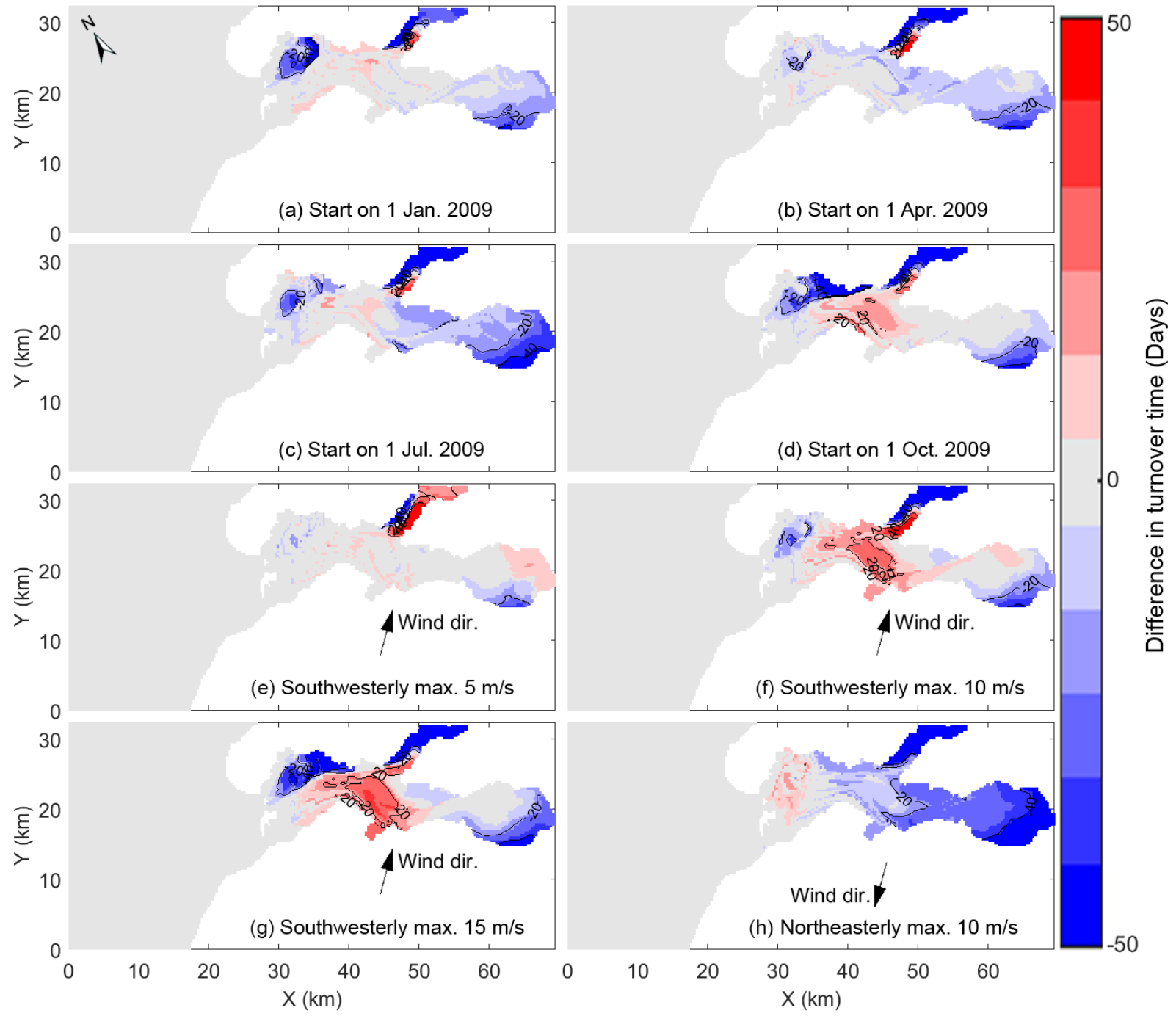

$X(\mathrm{~km})$

687 Fig. 6. Differences in turnover time distribution between "tides + winds" and "tide-only" 688 scenarios. The wind forcing is (a-d) realistic and (e-h) idealized with fixed direction: (a) W1 689 STP2, (b) W4 - STP2, (c) W7 - STP2, (d) W10 - STP2, (e) Wsw5 - STP2, (f) Wsw10 690 STP2, (g) Wsw15 - STP2, and (h) Wne10 - STP2. See Table 1 for details of scenarios. 


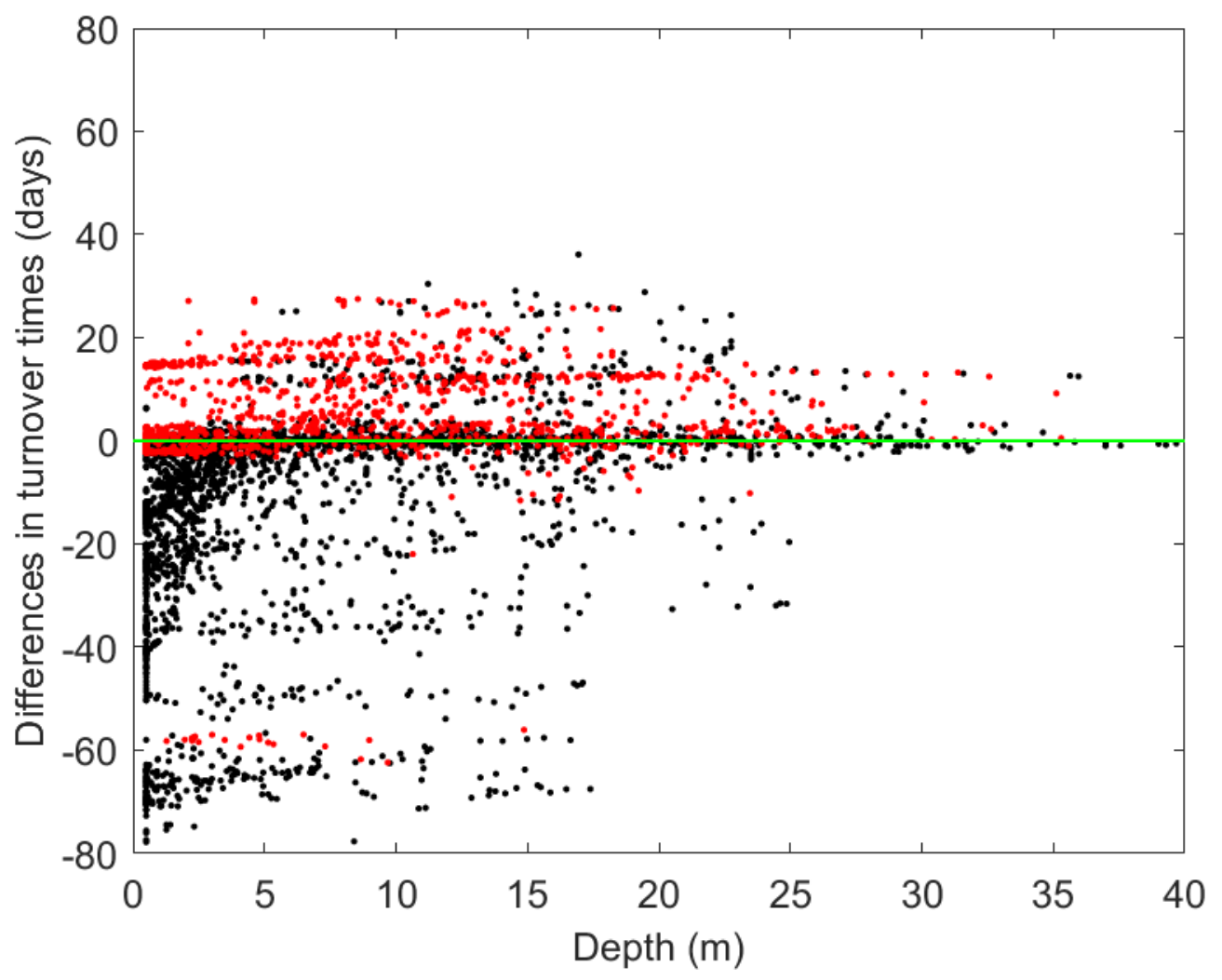

692 Fig. 7. Differences in turnover time between "tides + winds" and "tide-only" scenarios 693 (Wsw10 - STP2) versus water depth. Red and black points denote each $300 \mathrm{~m} \times 300 \mathrm{~m}$ grid 694 cell in the central and the other three compartments, respectively. The green line represents no 695 difference in turnover time. 

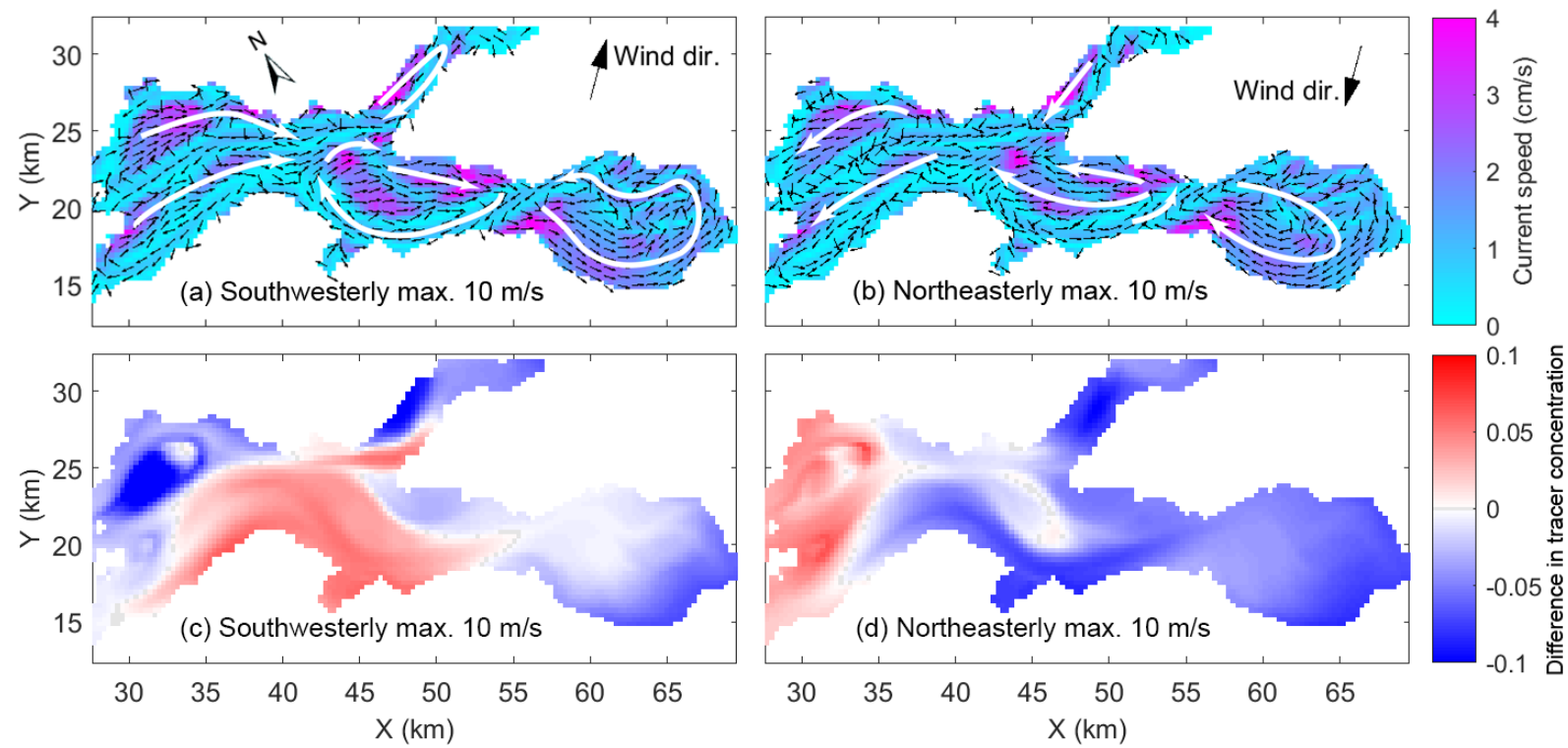

701

702

Fig. 8. (a and b) Depth-average residual currents in the first month of the experiment in scenarios Wsw10 and Wne10 with tide and idealized winds. (c and d) Difference of tracer concentration in these two scenarios from the baseline scenario during the same period. See Table 1 for details of the two scenarios. White arrows in (a) and (b) indicate the schematic circulation patterns. 


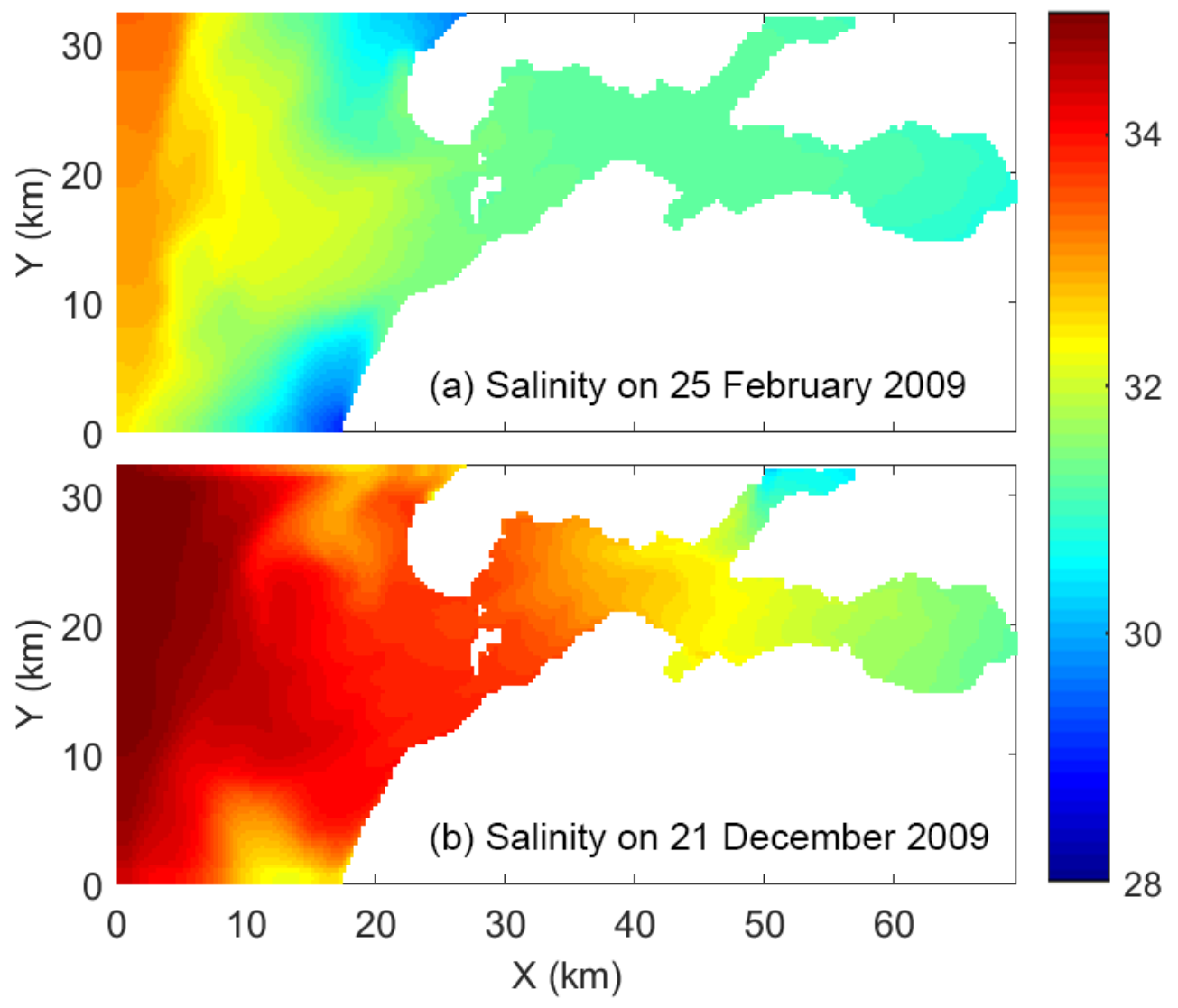

711 Fig. 9. Depth-average salinity snapshots on (a) 25 February and (b) 21 December 2009. These 712 two dates are marked in Fig. 3. 


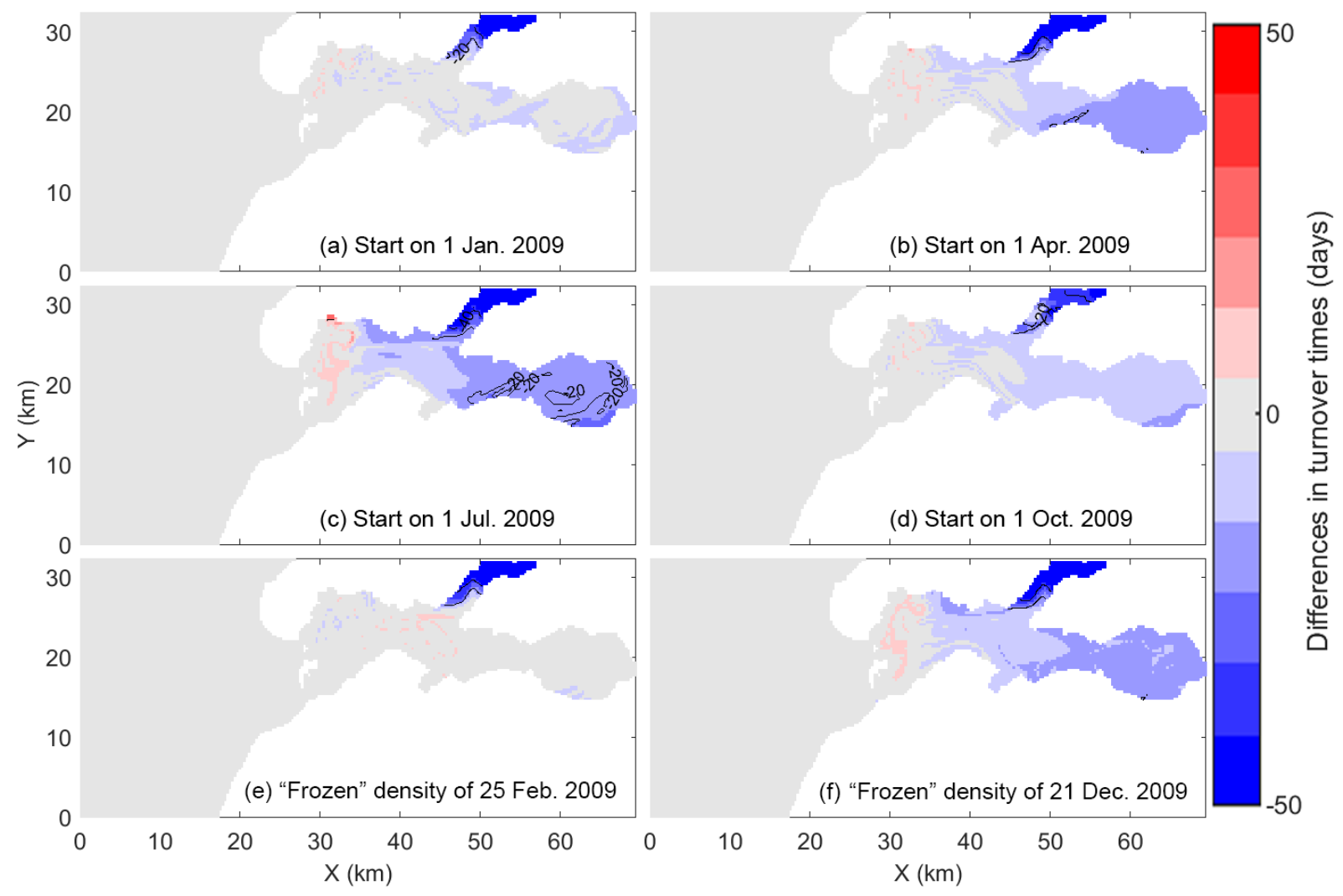

715 Fig. 10. Differences in turnover time distribution between "tides + gravitational flow" and 716 "tide-only" scenarios. Gravitational flow is (a-d) realistic and induced by (e and f) "fixed" 717 density: (a) G1 - STP2, (b) G4 - STP2, (c) G7 - STP2, (d) G10 - STP2, (e) GF1 - STP2, and 718 (f) GF4 - STP2. See Table 1 for details of scenarios. 

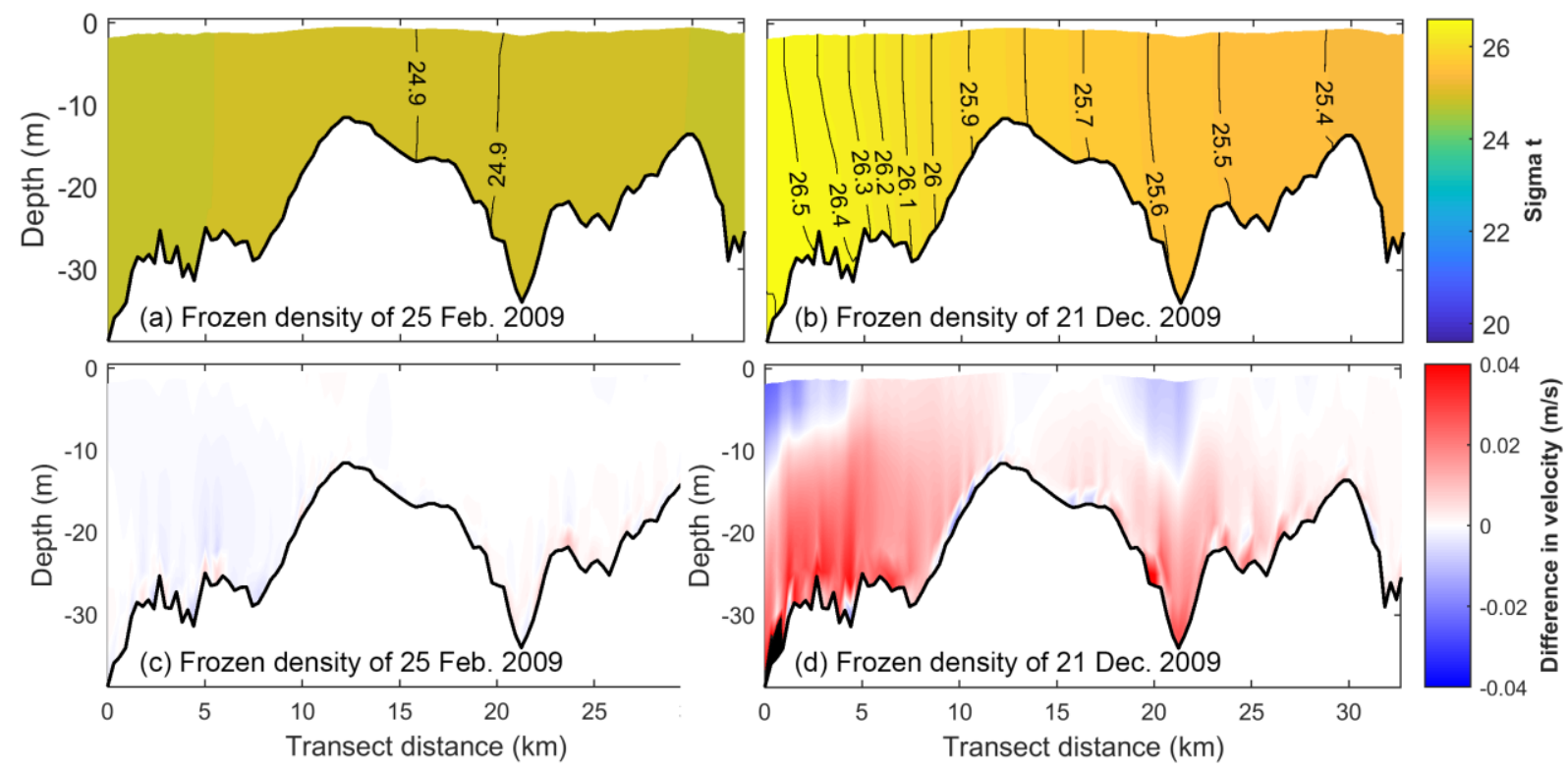

Fig. 11. Density on the transect along the southern channel (Fig. 1) of the Oosterschelde in scenarios (a) GF1 and (b) GF4 with tides and "fixed" gravitational forces. (c and d) Differences in along-channel velocity between "tides + gravitational flow" and "tide-only" scenarios: (c) GF1 - STP2 and (d) GF4 - STP2. See Table 1 for details of scenarios. 

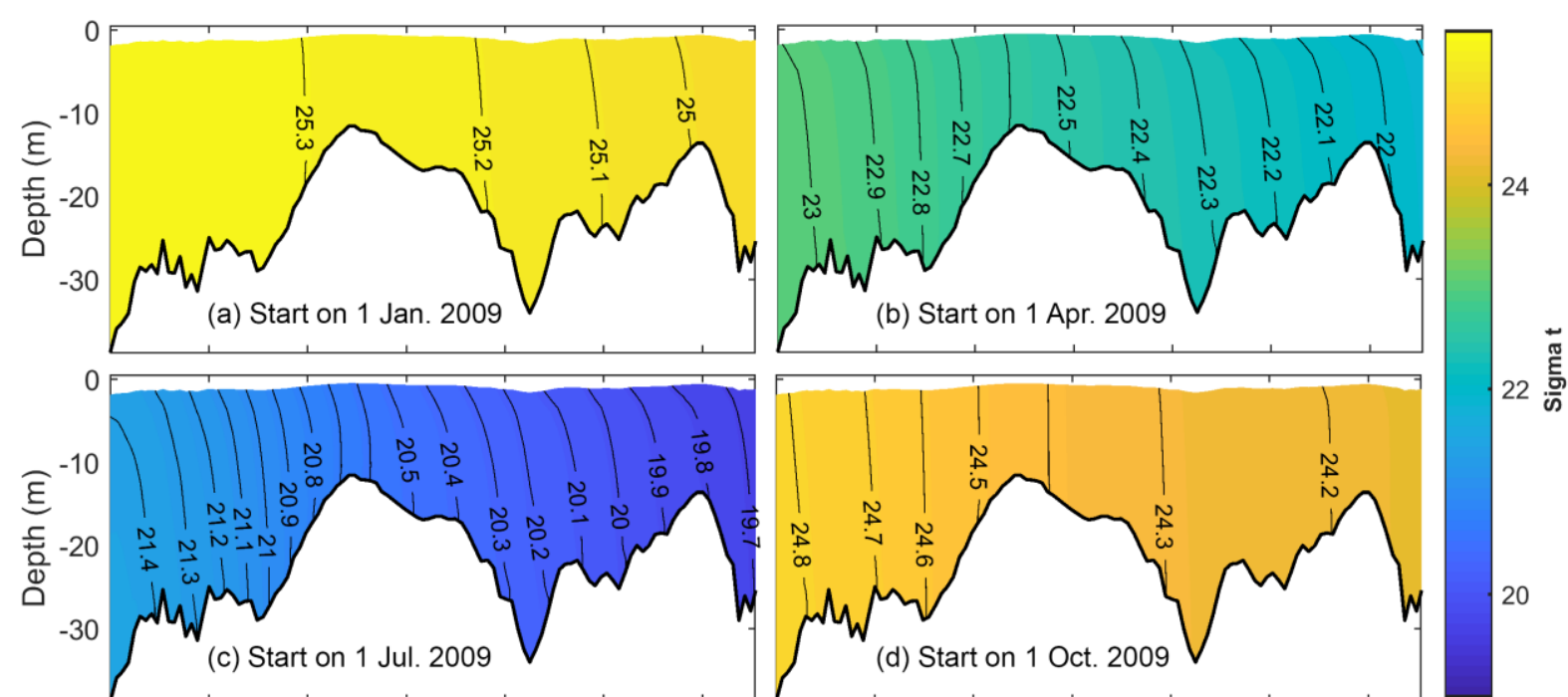

22 क요
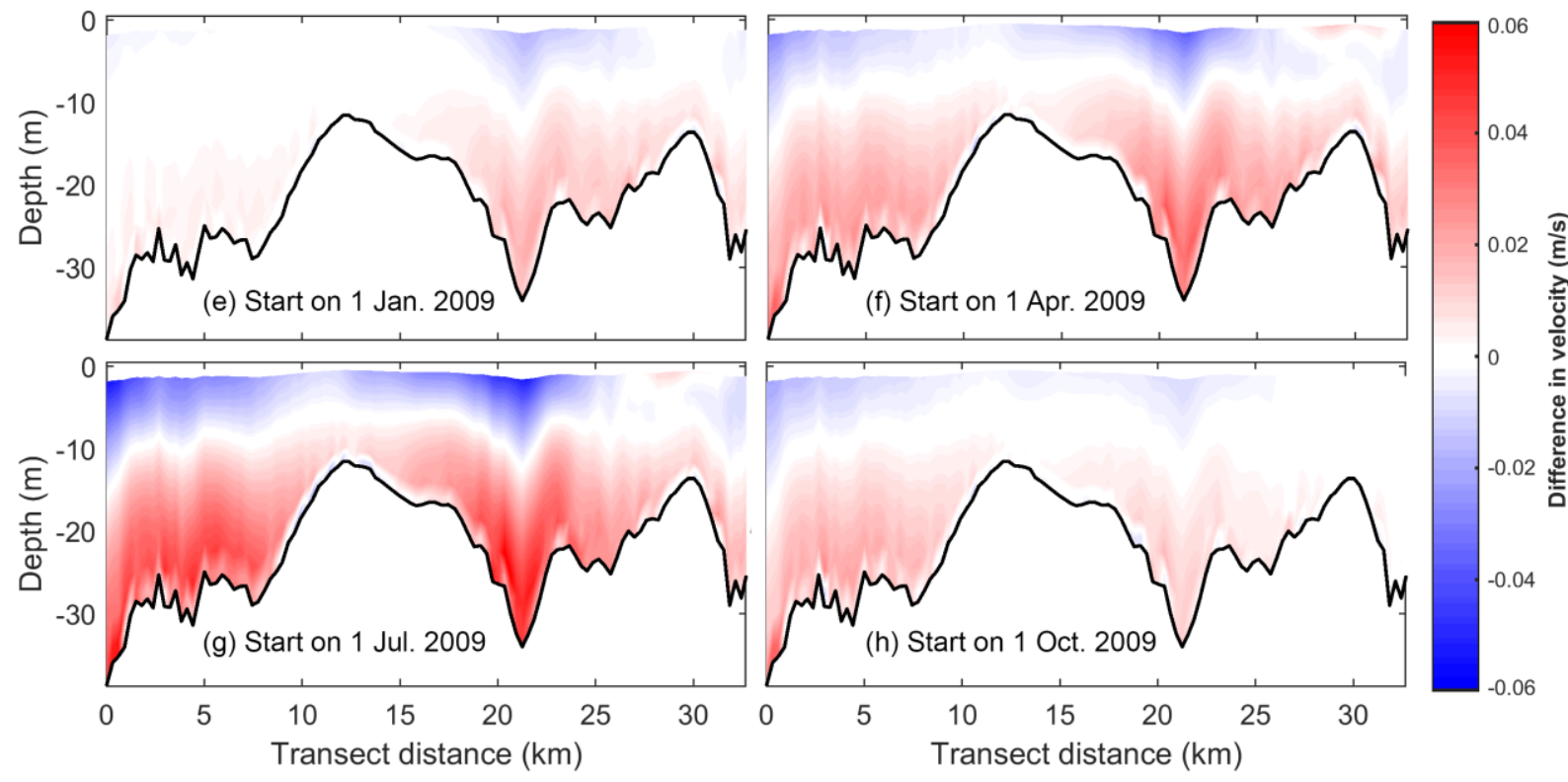

Fig. 12. (a-d) Density on the transect along the southern channel (Fig. 1) of the Oosterschelde in the first 90 days of scenarios G1, G4, G7, and G10 with tides and realistic gravitational forces. (e-h) Differences in along-channel velocity in the first 90 days between "tides + gravitational flow" and "tide-only" scenarios: (e) G1 - STP2, (f) G4 - STP2, (g) G7 - STP2, and (h) G10 - STP2. See Table 1 for details of scenarios. 